\title{
Effect of Thermal Processing on Key Phytochemical Compounds in Green Leafy Vegetables: A Review
}

\section{Nandya Putriani, Jimmy Perdana, Meiliana \& Probo Y. Nugrahedi}

To cite this article: Nandya Putriani, Jimmy Perdana, Meiliana \& Probo Y. Nugrahedi (2020): Effect of Thermal Processing on Key Phytochemical Compounds in Green Leafy Vegetables: A Review, Food Reviews International, DOI: 10.1080/87559129.2020.1745826

To link to this article: https://doi.org/10.1080/87559129.2020.1745826

\section{冓 Published online: 16 Apr 2020.}

Submit your article to this journal $\asymp$

Џll Article views: 139

Q View related articles $\widetilde{ }$

View Crossmark data $\nearrow$ 


\title{
Effect of Thermal Processing on Key Phytochemical Compounds in Green Leafy Vegetables: A Review
}

\author{
Nandya Putriani ${ }^{a}$, Jimmy Perdana ${ }^{a, b}$, Meiliana ${ }^{a}$, and Probo Y. Nugrahedi ${ }^{a}$ \\ ${ }^{a}$ Department of Food Technology, Soegijapranata Catholic University, Semarang, Indonesia; ${ }^{b}$ Department of \\ Science and Technology, Nestlé NPTC Food, Singen (Hohentwiel), Germany
}

\begin{abstract}
Green leafy vegetables are widely cultivated and consumed in South East Asia. These vegetables are rich in phytochemicals, which have been associated to particular health benefits. Preparation/processing, particularly those involving heat, prior to consumption can change the level of phytochemicals in the vegetables following various mechanisms, including thermal breakdown, oxidation, leaching, and matrix degradation. Appropriate processing should minimize degradation of phytochemicals so that the optimum intake toward health promotion be achieved. Better understanding of how processing influence the retention of phytochemical compounds is therefore crucial to provide guidelines on the processing of green leafy vegetables while maximizing their nutritional values.
\end{abstract}

\section{KEYWORDS}

Green leafy vegetables; phytochemicals; thermal processing; degradation; nutritional values

\section{Introduction}

For centuries, green leafy vegetables have been staples in the diets of South East Asian people. ${ }^{[1]}$ These vegetables contribute significantly to fulfill human nutrition needs. The vegetables contain a substantial amount of protein, carbohydrate, lipids, fibers, minerals, vitamins, and particularly, phytochemical compounds. ${ }^{[2,3]}$

Green leafy vegetables are consumed either raw or cooked/processed. Various types of processing are commonly applied to inactivate microorganism and enzymes leading to improved product safety and quality. Processings are also aimed to enhance palatability and to inactivate antinutritional compounds. ${ }^{[4,5]}$ Thermal processing methods commonly applied to green leafy vegetables are blanching, steaming, boiling, drying, microwave cooking, pressure cooking, and frying. Processing may cause significant changes in nutritional and especially phytochemical content in green leafy vegetables. ${ }^{[6,7]}$ Different methods of thermal processing can lead to various degree of changes of the phytochemical contents.

Therefore, the selection of an appropriate method to process green leafy vegetables should be critically considered. In this paper, we review the effect of processing methods on the retention of phytochemical compounds in green leafy vegetables. The retention level is calculated from previous publications reporting concentration of the phytochemicals both in the raw and the processed green leafy vegetables. The underlying mechanism leading to changes of phytochemical compounds in green leafy vegetables during processing are discussed by providing thorough information of each processing method, such as

CONTACT Probo Y. Nugrahedi probo@unika.ac.id 0 Department of Food Technology, Soegijapranata Catholic University, Jl. Pawiyatan Luhur IV/1 Bendan Duwur, Semarang, Indonesia 
time and temperature, pressure, and amount of water or oil, which lead to the changes via mechanisms of, e.g. cell lysis, matrix degradation, enzyme inactivation, thermal degradation, and oxidation. Previous studies have been reviewed the interaction of processing and bioavailability and bioaccessibility of phytochemicals in vegetables. ${ }^{[8-11]}$ The mechanism of absorption, distribution, metabolism, and excretion of phytochemicals have also been reviewed. ${ }^{[7,8,12-15]}$

\section{Phytochemicals in green leafy vegetables and their potential health benefits}

Vegetable consumption has been identified to promote health, e.g. against chronic diseases such as cardiovascular disease, diabetes, obesity, alzheimer, and cancer. ${ }^{[4,16]}$ These health benefits have been associated to, for example antioxidant and anticarcinogenic activities of phytochemical compounds in vegetables. Key phytochemicals in green leafy vegetables are phenolic compounds, ${ }^{[17]}$ carotenoids, ${ }^{[18]}$ chlorophyll, ${ }^{[19]}$ ascorbic acid, ${ }^{[20]}$ flavonoids, ${ }^{[21]}$ and glucosinolates, ${ }^{[22]}$ which will be briefly discussed in the following subsection.

\section{Polyphenols}

The phenolic compound is chemically defined as a compound containing an aromatic ring, which is linked with one or more hydroxyl group. ${ }^{[23]}$ The number and position of hydroxyl groups affect its ability to scavenge free radicals and chelate metal cations, which can decrease the risk of chronic disease. ${ }^{[24,25]}$ Total polyphenol concentration in green leafy vegetables varies between 23 and $231 \mathrm{mg}$ GAE/100 g fresh weight (FW) (Table 1). Most of the polyphenols in green leafy vegetables degrade during processing at $100^{\circ} \mathrm{C}$ or higher. ${ }^{[6,26,39]}$

Table 1. Phytochemical compounds in green leafy vegetables.

\begin{tabular}{llcc}
\hline Phytochemical compounds & \multicolumn{1}{c}{ Vegetables } & Concentration $(\mathrm{mg} / 100 \mathrm{~g} \mathrm{FW})$ & References \\
\hline Total polyphenol & Spinach & 23 & {$[26]$} \\
& Water spinach & 42 & {$[27]$} \\
& Celery & 35 & {$[28]$} \\
& Coriander leaves & 42 & {$[26]$} \\
& Cassava leaves & 50 & {$[29]$} \\
& Papaya leaves & 231 & {$[30]$} \\
& Chinese mustard & 63 & {$[31]$} \\
Carotenoid & Spinach & 2 & {$[32]$} \\
& Water spinach & 2 & {$[32]$} \\
& Coriander leaves & 5 & {$[33]$} \\
& Drumstick leaves & 7 & {$[32]$} \\
& Sweet potato leaves & 8 & {$[32]$} \\
& Lettuce & 3 & {$[34]$} \\
& Chinese mustard & 2 & {$[31]$} \\
Chlorophyll & Spinach & 1 & {$[20]$} \\
& Water spinach & 2 & {$[35]$} \\
& Celery & 4 & {$[36]$} \\
& Coriander leaves & 4 & {$[36]$} \\
Ascorbic acid & Drumstick leaves & 216 & {$[37]$} \\
& Spinach & 69 & {$[20]$} \\
& Water spinach & 16 & {$[35]$} \\
& Celery & 3 & {$[38]$} \\
& Drumstick leaves & 271 & {$[37]$} \\
& Cassava leaves & 48 & {$[29]$} \\
& Papaya leaves & 40 & {$[30]$} \\
& Chinese mustard & 31 & {$[31]$} \\
\hline
\end{tabular}


The bioavailability of polyphenols depends on the matrix composition and chemical structure that could be induced by food processing. ${ }^{[9,12]}$ Food processing causes degradation and modification of cell wall composition that can increase the bioavailability of polyphenols. ${ }^{[9]}$ The bioactive metabolites could be absorbed into the circulatory system and exert antioxidant activity that gives beneficial effect on human health. ${ }^{[40]}$ Cory et al. ${ }^{[41]}$ have also reviewed the impact of polyphenols on human health. The antioxidant and antiinflammatory properties of polyphenols were reported to reduce the risk of cancer, cardiovascular diseases, type 2 diabetes, obesity, and neurodegenerative diseases.

\section{Carotenoids}

Carotenoids are oil-soluble yellow-orange pigments that consist of isoprene units linked covalently in either a head-to-tail or tail-and-tail to form a symmetrical molecule. ${ }^{[20,42]}$ Carotenoids in vegetables are mostly located in chloroplasts and covered by chlorophylls. Therefore, the yellow-orange color of carotenoids becomes more evident when chlorophyll decomposes. ${ }^{[42]}$ Carotenoids commonly found in plants are in forms of lutein, zeaxanthin, lycopene, $\beta$-carotene, $\alpha$-carotene, dan $\beta$-cryptoxanthin. ${ }^{[18]}$ Lutein and $\beta$ carotene are the most dominant carotenoids in green vegetables. ${ }^{[43]}$

In green leafy vegetables, the carotenoid content ranges between 2 and 8 g/100 g FW (Table 1). Carotenoids are mostly bound to proteins that may decrease their bioavailability. The absorption of carotenoids is also influenced by dietary fat. Dietary fat and bile salt could be bound with the carotenoid to form micelles that allow carotenoid absorption to the intestine. Fortunately, appropriate processing could increase carotenoid bioavailability by breaking down the cell wall and protein-carotenoid complexes. Processing combined with oils also can increase the bioavailability of carotenoids. ${ }^{[40,43]}$

The diffusion of carotenoids from the blood circulatory system to various tissues by lipoprotein could provide beneficial effects on human health. ${ }^{[43]}$ Carotenoids could protect the cellular membranes and lipoproteins against photooxidative damage in plant and human due to their ability to scavenge reactive oxygen species, singlet molecular oxygen, and peroxyl radicals. Carotenoids also contribute to macular pigment formation that could absorb harmful blue light. Thus, increased consumption of a diet rich in carotenoids could reduce the risk of diseases such as erythema, cancer, cardiovascular-linked diseases, light blindness, keratomalacia, xerophthalmia, cataract, and macular degeneration. ${ }^{[4,45]}$

\section{Chlorophyll}

Chlorophyll structurally consists of a porphyrin ring containing a magnesium ion located at the center. ${ }^{[42]}$ Various levels of chlorophyll in green leafy vegetables were reported, ranging from 1 to $216 \mathrm{mg} / 100 \mathrm{~g}$ FW (Table 1). Heat treatment can lead to the formation of pheophytin because magnesium in chlorophyll can be easily displaced by two hydrogen atoms. The harsher thermal load may eventually remove the carbomethoxy group in chlorophyll to form pirochlorophyll. Further heating can release either magnesium atom in pirochlorophyll or carbomethoxy group in pheophytin to form piropheophytin. ${ }^{[4]}$

Interestingly, the conversion of chlorophyll to pheophytin, pyropheophytin, and pheophorbide during processing can increase the bioavailability of chlorophyll. Chao et al. ${ }^{[47]}$ showed that pheophytin and pheophorbide are the main chlorophyll derivates found in the 
human blood, indicating chlorophyll derivates might be easily absorbed. Chlorophyll derivates are reported to possess antioxidant, antimutagenic, and anticancer activity. ${ }^{[8]}$

Moreover, an in vivo and in vitro study reported chlorophyll could suppress pancreatic cancer cell viability by inhibiting heme oxygenase mRNA expression and enzymatic activity. ${ }^{[49]}$ Antioxidant activity in chlorophylls and their derivates can prevent oxidative DNA damage and lipid peroxidation by chelating reactive ions and scavenging free radicals. ${ }^{[19]}$

\section{Ascorbic acid}

Ascorbic acid, or commonly known as vitamin $\mathrm{C}$ that presents mostly in L-ascorbic acid form, is the enolic form of 3-keto-L-glucofuranolactone. ${ }^{[50]}$ Table 1 shows the broad spread of ascorbic acid content in various green leafy vegetables. Among others, drumstick leaves notably contain the highest level of ascorbic acid, while celery has the lowest. ${ }^{[20,29-31,35,37,38]}$

$\mathrm{L}$-ascorbic acid can terminate radical chain reaction, scavenge reactive species, donate an electron to a substrate, and regenerate other antioxidant compounds that may protect DNA and protein from oxidative stress. ${ }^{[13]}$ Accordingly, ascorbic acid was reported to improve the utilization of iron and prevent cardiovascular diseases, cancer, cataracts, type 2 diabetes, and inflammation due to their antioxidant and antihistamine effects. ${ }^{[38,51]}$ Unfortunately, ascorbic acid is easily degraded via oxidation reaction, especially when catalyzed by metal ions (i.e. $\mathrm{Cu}^{2+}$ and $\mathrm{Fe}^{3+}$ ). Heat, light, and oxygen may accelerate oxidation. ${ }^{[42]}$ The enediol groups at carbon atom numbers 2 and 3 are prone to oxidation and can be easily altered to diketo groups. This transforms ascorbic acid to dehydroascorbic acid. ${ }^{[50]}$ Dehydroascorbic acid is unstable at physiological $\mathrm{pH}$ and it is easily converted to 2,3 diketogulonic acid. The alteration of ascorbic acid to dehydroascorbic acid is reversible but the products of the latter oxidation stages are irreversible. ${ }^{[38]}$ Most ascorbic acid is therefore lost during processing, cooking, and storage.

\section{Glucosinolates}

Glucosinolates are a group of secondary plant metabolites in family Cruciferae or Brassicaceae, such as broccoli, Chinese mustard, pak choi, kale, and cabbage. ${ }^{[52]}$ A glucosinolate consists of $\beta$ D-thioglucoside $\mathrm{N}$-hydroxysulphate, which is a sulphur-linked $\beta$-D-glucopyranose moiety and a side chain (R). ${ }^{[53]}$ Natella, Maldini, Leoni, \& Scaccini ${ }^{[52]}$ reported that glucosinolates have a weak antioxidant capacity. Two glucosinolates, i.e. sinalbin and gluconasturtiin were found to quench ABTS radical and to chelate copper that leads to low-density lipoprotein inhibition, respectively. Nevertheless, isothiocyanates, ones of the derivative products of glucosinolates were reported to play a role as cancer chemo-preventive. ${ }^{[54,55]}$ Reviews on the effect of thermal processing on glucosinolates in vegetables can be found elsewhere. ${ }^{[22,56,57]}$

\section{Processing methods and their impacts on phytochemical compounds in green leafy vegetables}

\section{Blanching}

During blanching, vegetables are briefly exposed to hot water or steam. It is usually carried out preceding other processes (e.g. freezing, canning, or drying) to inactivate enzymes, modify the textures, and preserve color. Hot water blanching is performed at temperatures 
between $70^{\circ} \mathrm{C}$ and $100^{\circ} \mathrm{C}$ for 2 to $5 \mathrm{~min}$, followed by rapid cooling. Steam blanching is carried out at $100^{\circ} \mathrm{C}$ at a considerably shorter time than water blanching because the heat transfer of condensing steam is more efficient than hot water. ${ }^{[58]}$

The impact of blanching on phytochemical compounds varies depending on the type of vegetables and the blanching parameters as summarized in Table 2. Hot water blanching reduced phenolic compounds, carotenoids, and flavonoids in water spinach, celery, pak choy, Chinese mustard, black night shade, and jute mallow. Decrease of phenolic compounds, flavonoids, and carotenoid are often associated with thermal degradation, leaching from vegetable tissue into the blanching water ${ }^{[26,39,60]}$, oxidation reaction, and isomerization. ${ }^{[61]}$ In contrast, various levels of increase of total phenolic content after blanching have been reported in coriander leaves (36\% to $156 \%$ after water blanching and $11 \%$ to $131 \%$ after steam blanching) and nearly eight-fold in basil. $^{[27,59]}$ Blanching can liberate phenolic compounds such as hydroxycinnamic acid (which is bound to cell polymer and chlorogenic acid), thus improves its extractability upon analytical measurement. Inversely, the prolonged or higher temperature of blanching decreased the retention of total polyphenolic content in coriander leaves. ${ }^{\text {[59] }}$

Increase of flavonoids bioavailability in spinach and cassava leaves have also been reported. ${ }^{[62]}$ The underlying mechanisms involve disruption of hydrogen bonding of complex molecules, which then liberates flavonoids from leaf matrices. Blanching for a short time (30 s) increased chlorophyll content in basil and coriander leaves of 23\% and 169\%, respectively. This short time blanching facilitates the breakdown of organelles that contain phytochemical compounds, while the degradation can be maintained minimal. ${ }^{\text {[27] }}$

In general, blanching decreases of phytochemical compounds due to oxidation reaction, thermal degradation, enzymatic degradation, and disruption of vegetable tissue which release water-soluble phytochemical compounds into the processing medium. However, this disruption may also lead to higher extractability of the compounds.

\section{Boiling}

Boiling is the most common method to cook green leafy vegetables. Cooking affects membrane disruption, loss of turgor, and reduction of cell adhesion strength, which will lead to loss of firmness or softening. ${ }^{[63]}$ Boiling time of green leafy vegetables may vary, depending on the type of vegetables and consumer preferences in relations to, e.g. texture, color, and taste. ${ }^{[22,64]}$ From the phytochemical retention perspective, boiling is more suitable for processing vegetables that contain fat-soluble compounds, such as carotenoid, due to less diffusion and leaching into cooking water. ${ }^{[65,66]}$

Generally, boiling reduces phytochemicals in vegetables (Table 3), which is considered higher than that of blanching, and the magnitude is highly varied. Boiling leads leaching of water-soluble phytochemical compounds into the cooking medium. ${ }^{[39]}$ Thermal degradation of heat-sensitive compounds such as ascorbic acid ${ }^{[81,85]}$, oxidation, and degradation of, e.g. chlorophyll into their derivates such as pheophytin further reduces the phytochemical compounds of vegetable subjected to boiling. Acidic cooking condition and longer cooking times facilitate the formation of pheophytin. ${ }^{[17,79]}$ Leaching and degradation of the phytochemical compounds are higher during boiling than blanching due to the extended time and temperature applied during boiling. ${ }^{[39,61]}$ 


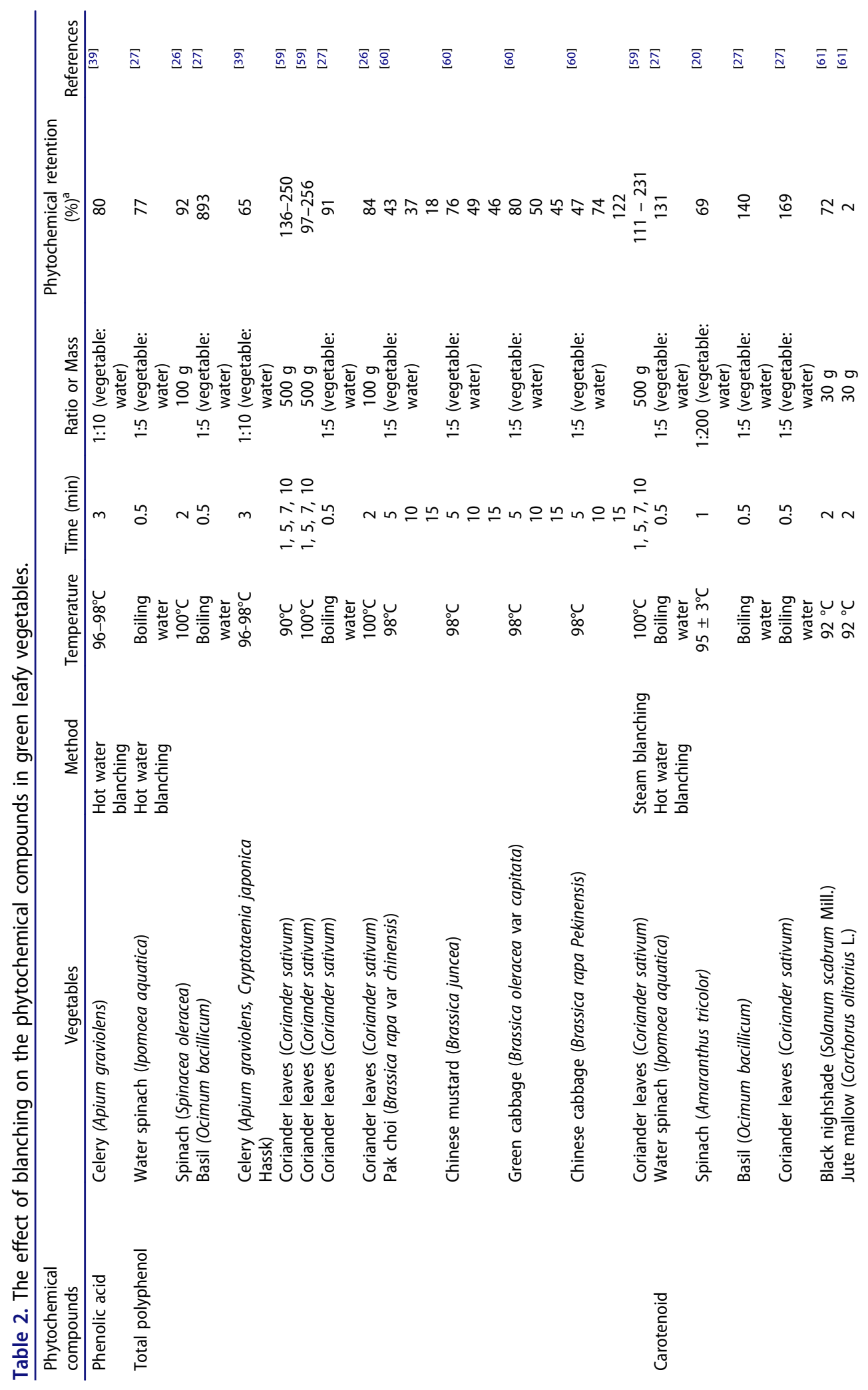


స్ర

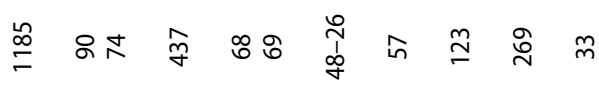

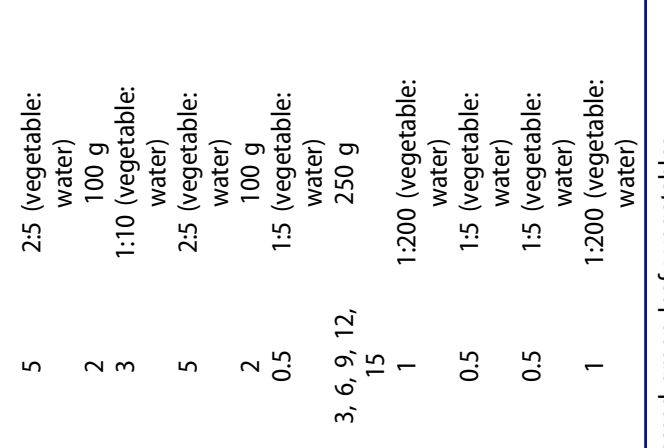

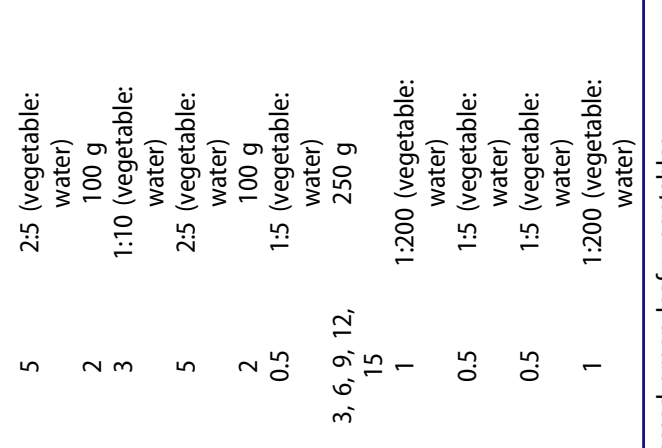

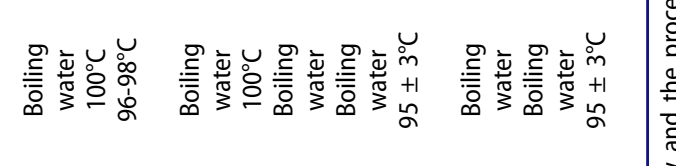

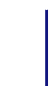

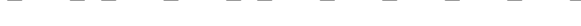

प1

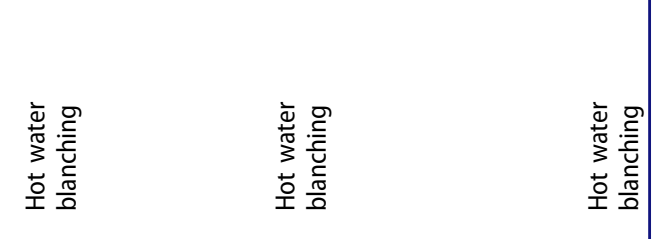

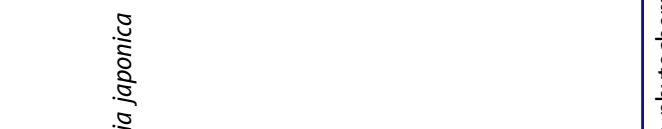

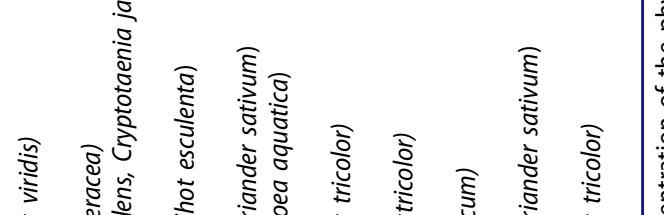

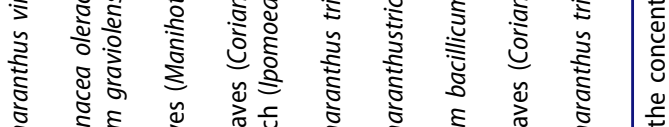

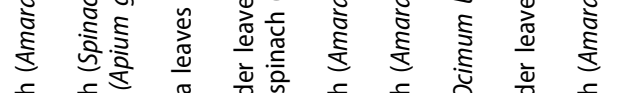

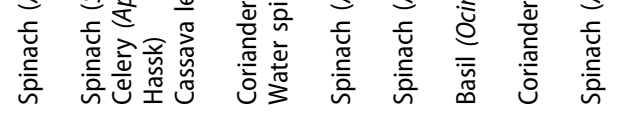

111 


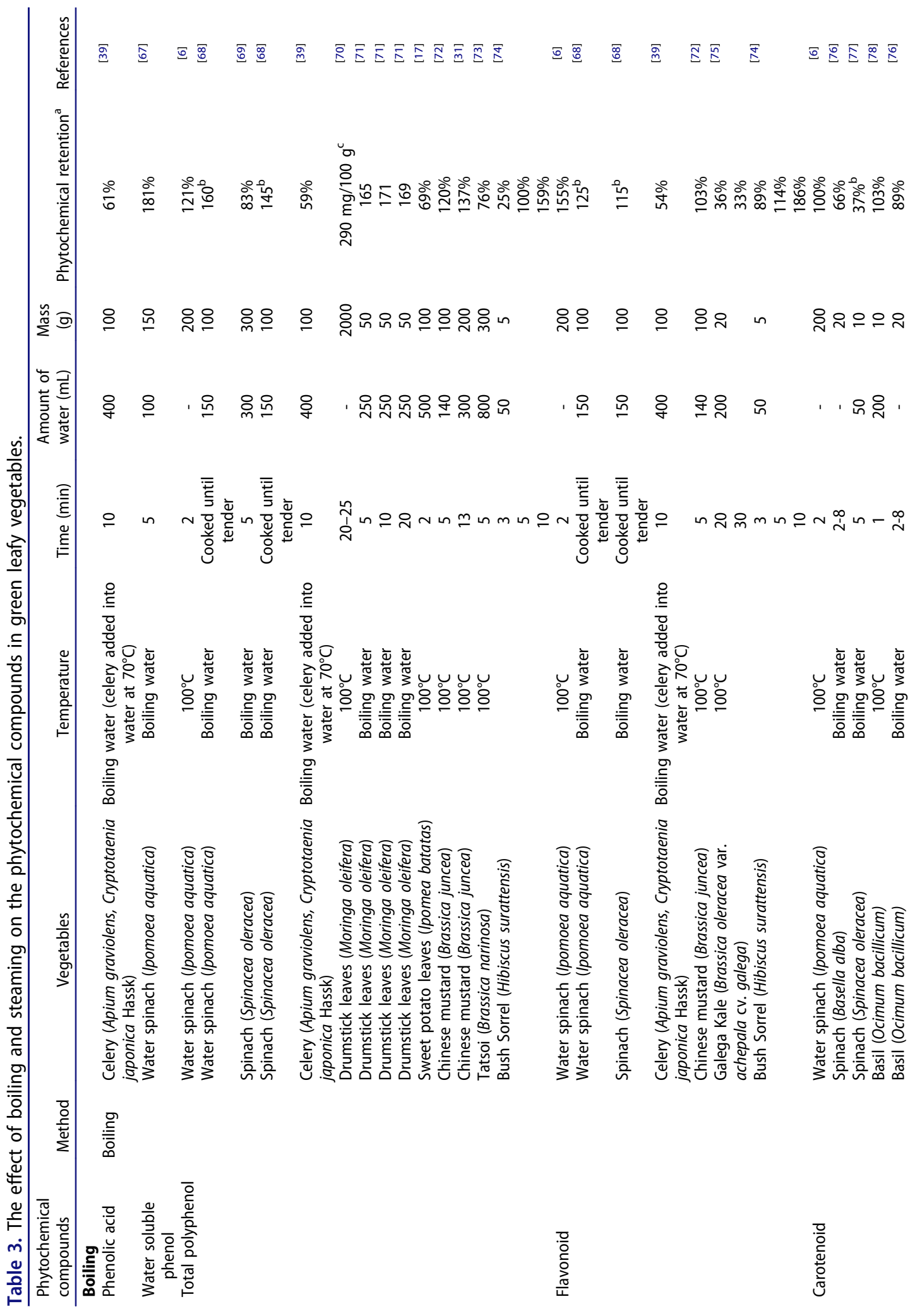


FOOD REVIEWS INTERNATIONAL

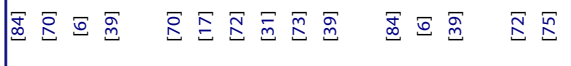

品

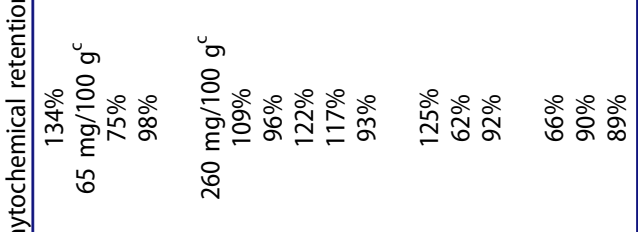

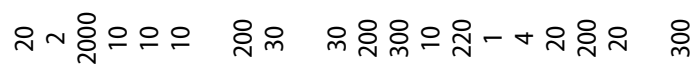

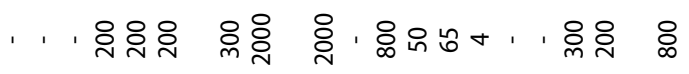

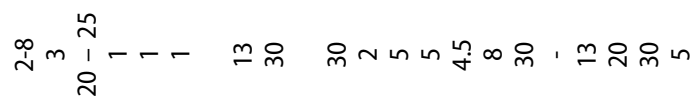

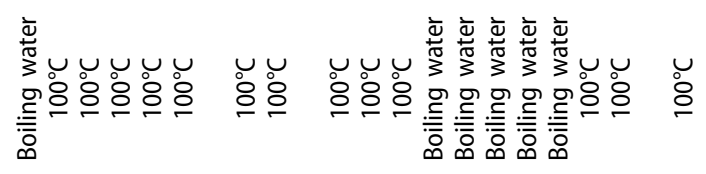
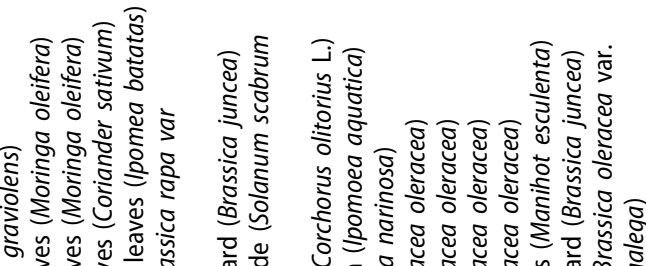

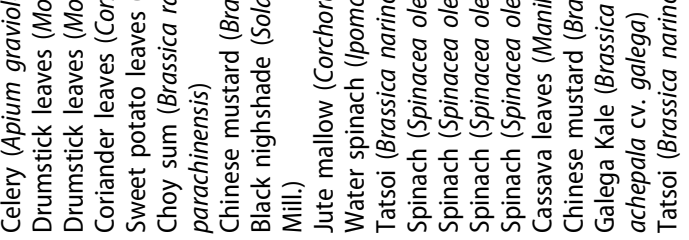

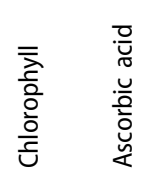

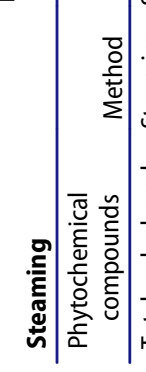

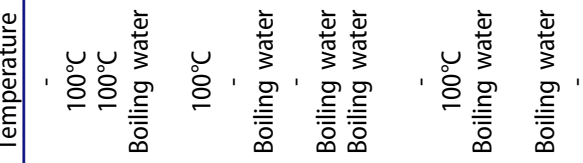

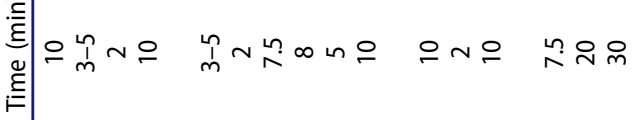

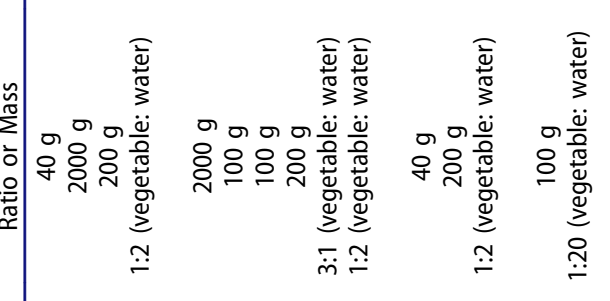

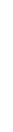

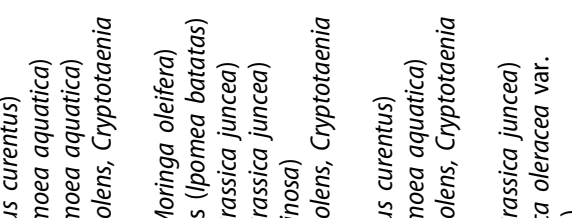

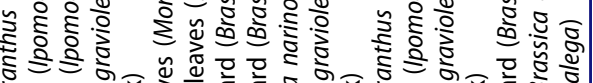

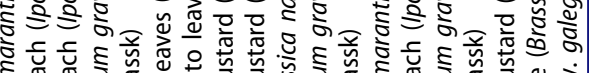

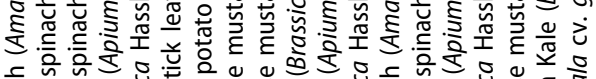

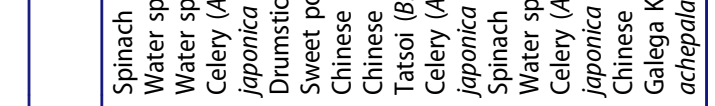




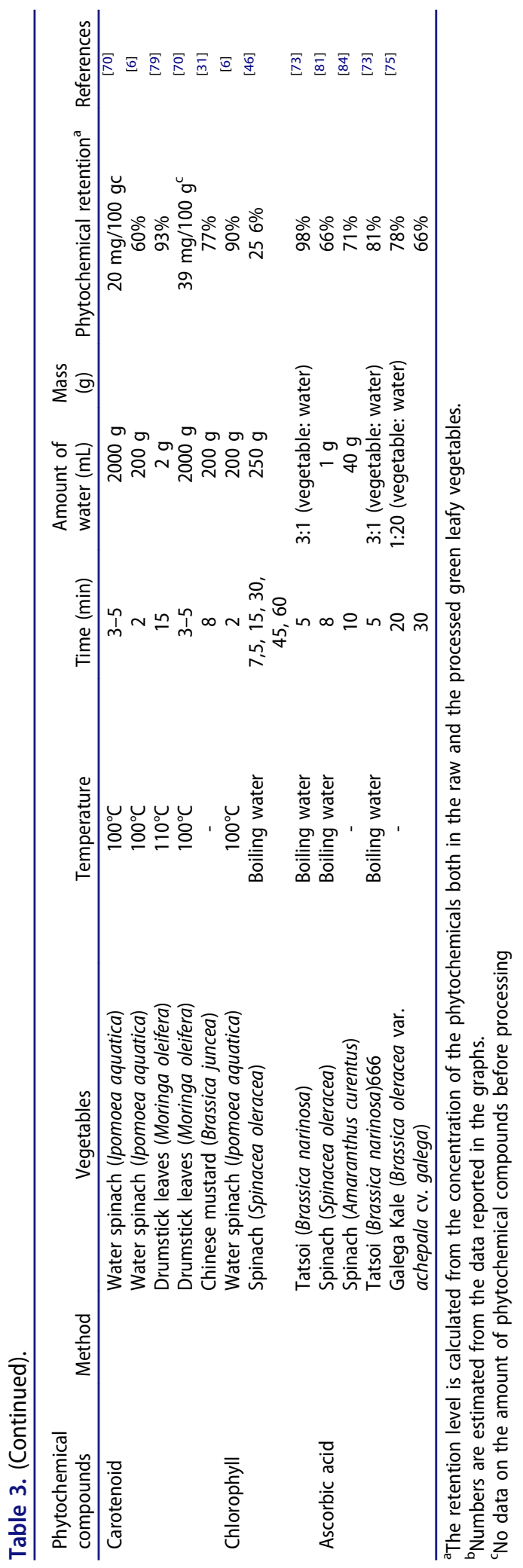


In contrast, $\mathrm{Ng}$ et al. ${ }^{[67]}$ reported that the concentration of water-soluble polyphenol compounds in boiled water spinach was $81 \%$ higher as compared to the ones in raw spinach. ${ }^{\text {[67] }}$ Boiling notably increased total polyphenol and flavonoid contents in water spinach, drumstick leaves, and Chinese mustard. ${ }^{[6,71,72]}$ Accordingly, a slight increase of $\beta$-carotene after boiling was found in basil, coriander leaves, sweet potato leaves, and pak choi. ${ }^{[78]}$

Similar to blanching, the increase of phytochemical compounds is likely an artifact due to the softening of the vegetable matrix due to heat, which subsequently increases extractability. ${ }^{[71,74]}$ An in vitro study reported that boiling could enhance the extractability of polyphenols in Bidens pilosa leaf matrix. Although bioaccessibility of polyphenols reduced after duodenal digestion, polyphenols still have sufficient antioxidant activity to protect cells from oxidative damage. ${ }^{[66]}$ Gehse et al. ${ }^{[86]}$ also reported short boiling time (less than $10 \mathrm{~min}$ ) could increase the bioavailability of carotenoid in vegetables. This is due to disruption of the carotenoid-protein complexes, inactivation of carotenoid oxidizing enzymes, ${ }^{[78]}$ the formation of secondary plant metabolites, destruction of complex phenolics, ${ }^{[6,66,69]}$ and release of active aglycones from flavonoid conjugates. ${ }^{[67]}$

\section{Steaming}

Steaming is probably the most appropriate cooking method to retain water-soluble phytochemical compounds in vegetables. ${ }^{[75,81]}$ This is due to the fact that during steaming vegetables are actually not in direct contact with water. ${ }^{[87]}$ Loss of nutritional contents after steaming is, however, still observed in green leafy vegetables (Table 3). Thi \& Hwang ${ }^{[6]}$ reported that steaming at temperature $100^{\circ} \mathrm{C}$ for 2 min reduced the concentration (in dry weight basis) of polyphenol, flavonoid, carotenoid, and chlorophyll in water spinach. Minor loss of carotenoid in drumstick leaves, ${ }^{[79]}$ total polyphenol and flavonoid in celery, ${ }^{[39]}$ and ascorbic acid in tatsoi ${ }^{[73]}$ were also observed. Thermal degradation is suspected of playing a major role in the loss of phytochemical compounds during steaming. ${ }^{[6,79,84]}$

Teng \& Chen ${ }^{[46]}$ reported a slight increase in chlorophyll degradation in spinach with heating time and temperature. The formation of pheophytin (a marker of chlorophyll degradation) is higher during wet heating methods (steaming, blanching) than dry heating methods (baking, microwaving cooking). This is probably because the liberation of organic acids from the leaf matrices due to moist heat are greater than due to dry heat. Moreover, higher heating time and temperature may facilitate the removal of the carbomethoxy group from chlorophyll. ${ }^{[46]}$

In contrast, an increase of total polyphenol concentration in sweet potato leaves (by about $9 \%)$ and in spinach (34\%) and increase of flavonoid compounds in spinach (25\%) after steaming have been also reported. ${ }^{[1]}$ It is likely that the strength of the cell walls influences the amount of extracted phytochemicals after steaming. ${ }^{[8]}$ It was reported that the breakdown of cell wall due to heating might promote the release of phenolic compounds from vegetable tissue ${ }^{[84]}$ and the breakdown of complex structures, thus liberating the phenolic compounds. ${ }^{[17]}$

Yao and $\operatorname{Ren}^{[39]}$ reported that steaming retains more polyphenol, phenolic acid, and flavonoid in celery than blanching or boiling. In steaming, direct contact between vegetables tissue and water is avoided, which significantly minimize losses of water-soluble phytochemical compounds through leaching. Steaming may also increase the bioaccessibility of 
micronutrients such as lutein, $\beta$-carotene, and $\alpha$-tocopherol through cell ruptures. ${ }^{[79]}$ Breakdown of cellulose structure and denaturation of carotenoid-protein complexes may be responsible for the increase of carotenoid content of vegetables after steaming. ${ }^{[6]}$

\section{Drying}

Drying is often applied to increase shelf life by preventing the microbial growth and enzymatic reaction through the reduction of water content and water activity. ${ }^{[89]}$ Proper selection of appropriate drying methods is crucial to retain aroma, appearance, and nutritional characteristics ${ }^{[90,91]}$ while optimizing the energy (cost) efficiency. ${ }^{[92-94]}$ Various drying methods are commonly applied to green leafy vegetables, such as shade drying, sun drying, oven drying, cabinet drying, and freeze-drying. ${ }^{\text {[95] }}$

During shade drying, significant reduction of ascorbic acid in drumstick leaves, papaya leaves, and spinach was reported. To a lesser degree, shade drying also reduced the availability of carotenoid and flavonoid content. ${ }^{[20,30,96]}$ During shade drying, despite carried out at relatively low temperatures $\left(30-35^{\circ} \mathrm{C}\right)$, long drying time (1-3 weeks) significantly decreased phytochemical contents in vegetables. ${ }^{[20,97]}$ Shorter drying time during oven drying and the absence of thermal load during freeze-drying ensured a lower degree of thermally induced degradation of heat-sensitive chlorophylls. ${ }^{[30]}$ In contrast, the increase of available chlorophyll of $147 \%$ and carotenoid of $36 \%$ has been reported for shade drying of spinach. ${ }^{[20]}$ Raja et al. ${ }^{[30]}$ also reported the increase of total phenolic content in papaya leaves between $6 \%$ and $15 \%$ after shade drying. This could be due to the formation of new products from maillard reaction during heating. ${ }^{\text {[98] }}$

Sun drying has been reported to decrease phytochemical compounds (phenolic, flavonoid, carotenoid, ascorbic acid, and chlorophyll) in green leafy vegetables ranging from $35 \%$ to $100 \%$ (Table 4). Sriwichai et al. ${ }^{[79]}$ reported a 63\% decrease of carotenoid content in drumstick leaves upon sun drying, which is more severe than that of steaming, freezing, and sterilization. Direct light exposure is hypothesized to induce the oxidation reaction of heat-sensitive phytochemical compounds in green leafy vegetables. ${ }^{[37]}$ Moreover, grinding prior to drying can increase the contact area of vegetable and air/light, which subsequently increases the rate of autooxidation. ${ }^{[79,109]}$

Speek et al. ${ }^{[76]}$ reported the decrease of carotenoid in spinach (51\%) and basil (55\%) after sun drying, which likely relates to decomposition and trans-cis isomerization of carotenoid. During sun drying, chlorophyll may be transformed into pheophytin via the displacement of magnesium by a hydrogen atom. Chlorophyll $\mathrm{A}$ is more susceptible to thermal degradation than chlorophyll B. Thus, after sun drying the decrease of chlorophyll A is usually more pronounced than chlorophyll B. ${ }^{[35]}$

After sun drying total polyphenol, carotenoid, and chlorophyll in spinach increased by $223 \%,{ }^{[100]} 5 \%{ }^{[20]}$ and $109 \%,{ }^{[20]}$ respectively. Similarly, a dramatic increase of total polyphenol in cassava leaves and chlorophyll in water spinach after drying has been reported. ${ }^{[20,29,100]}$ This may be explained by the increase of dry solid in the vegetable matrices, ${ }^{[10]}$ increase extractable carotenoid via release from matrix cell, ${ }^{[18,35]}$ and/or breakdown of the cell wall during drying, which disturbs the bond of phenolic compounds. ${ }^{[97]}$

After oven drying, most of the phytochemical compounds (phenolic, flavonoid, carotenoid, chlorophyll, and ascorbic acid) in green leafy vegetables decreased between $4 \%$ and $100 \%$ (Table 4). Saini et al. ${ }^{[37]}$ reported that cabinet drying of drumstick leaves decreased 


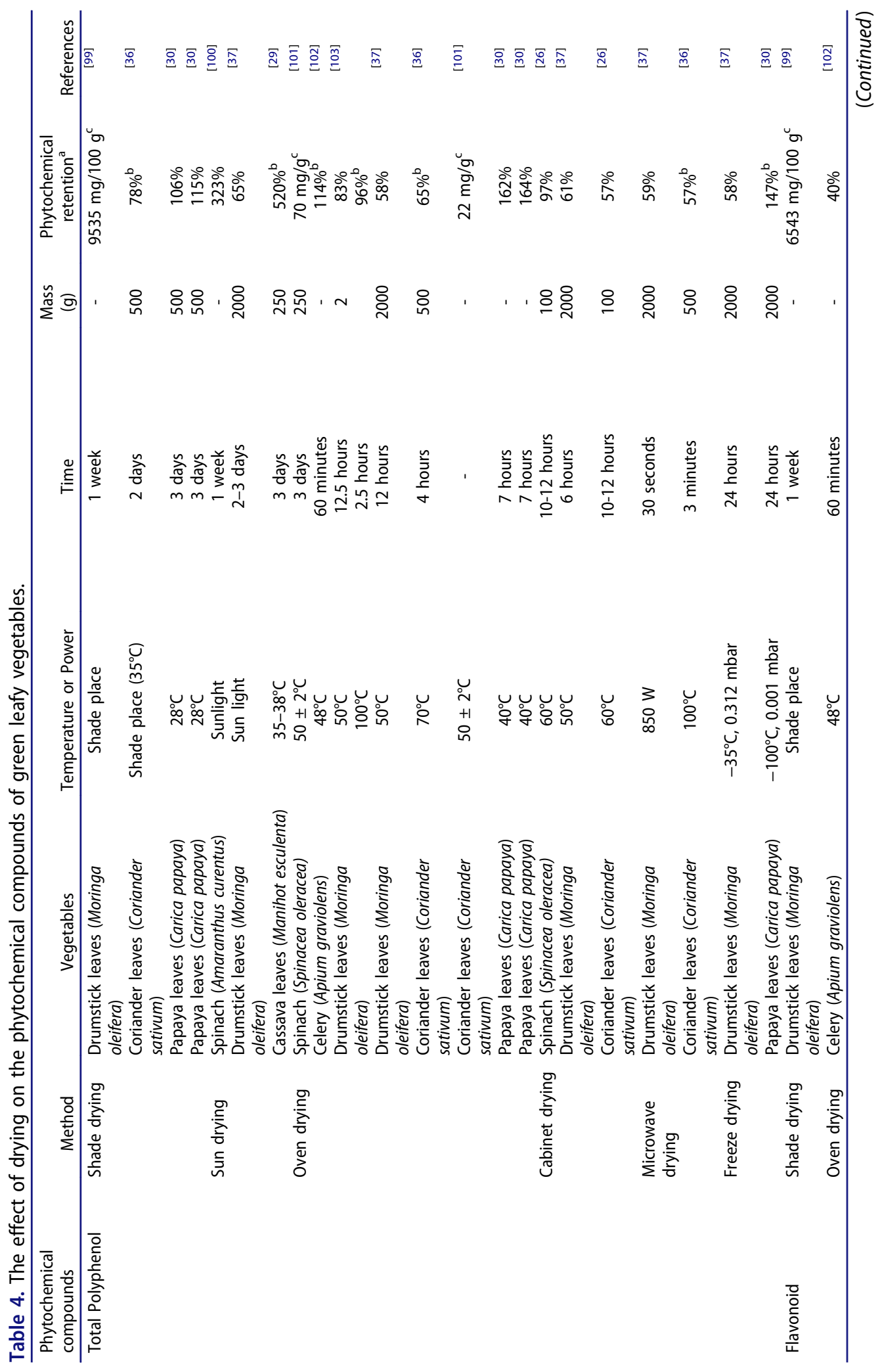




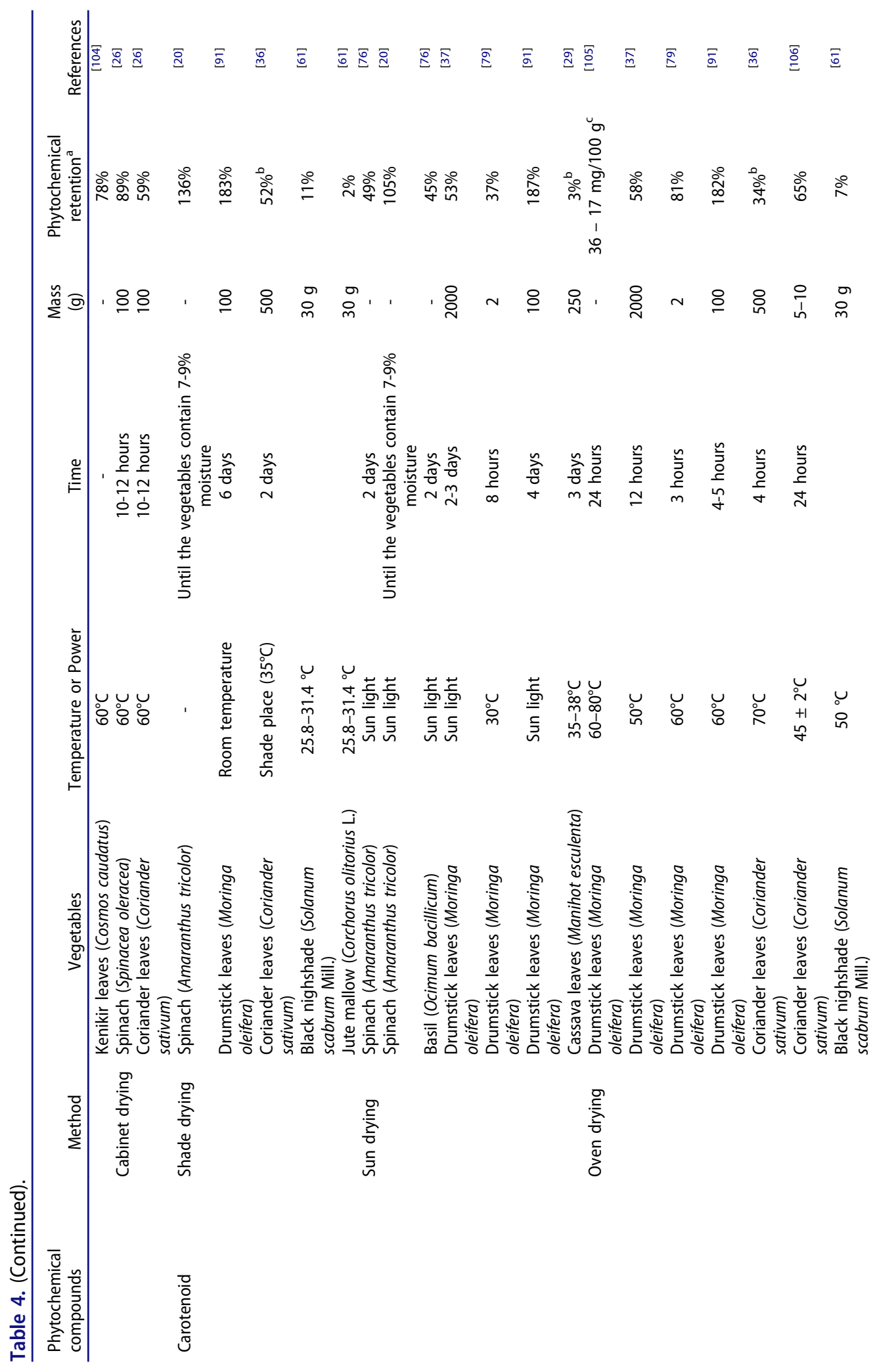




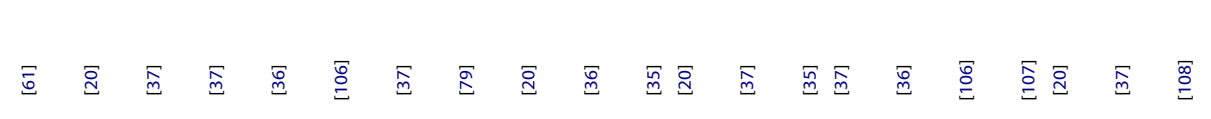

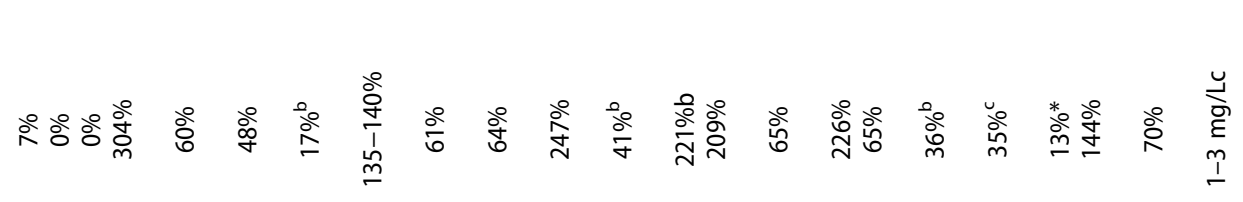
일, 囟

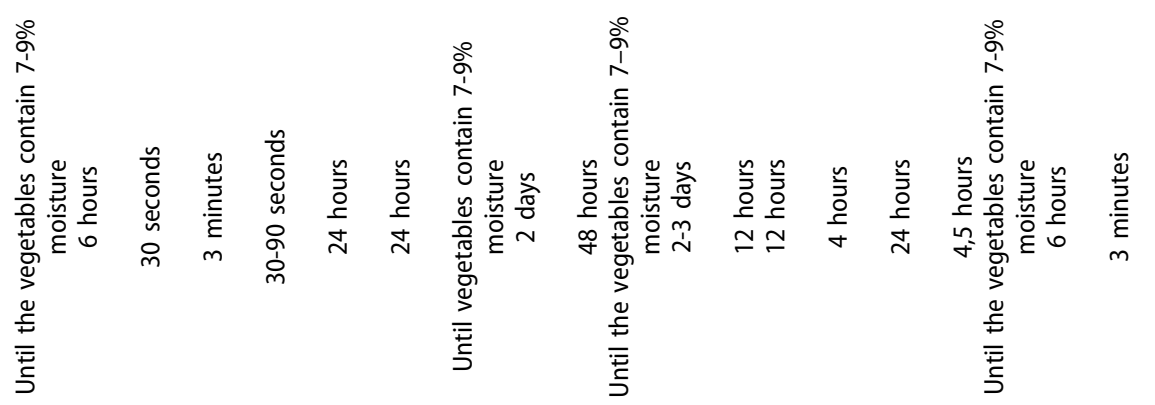

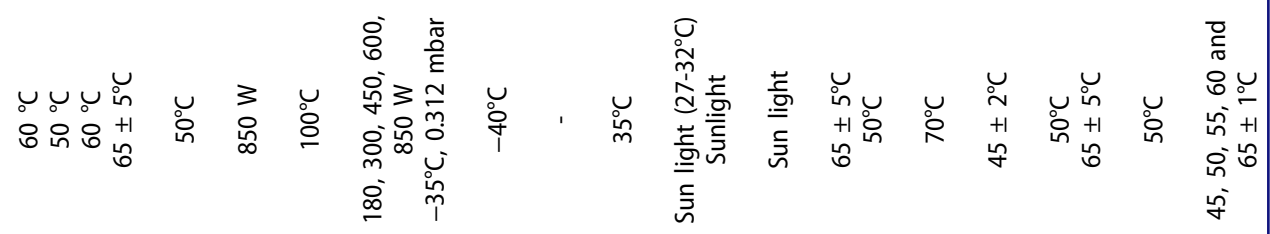

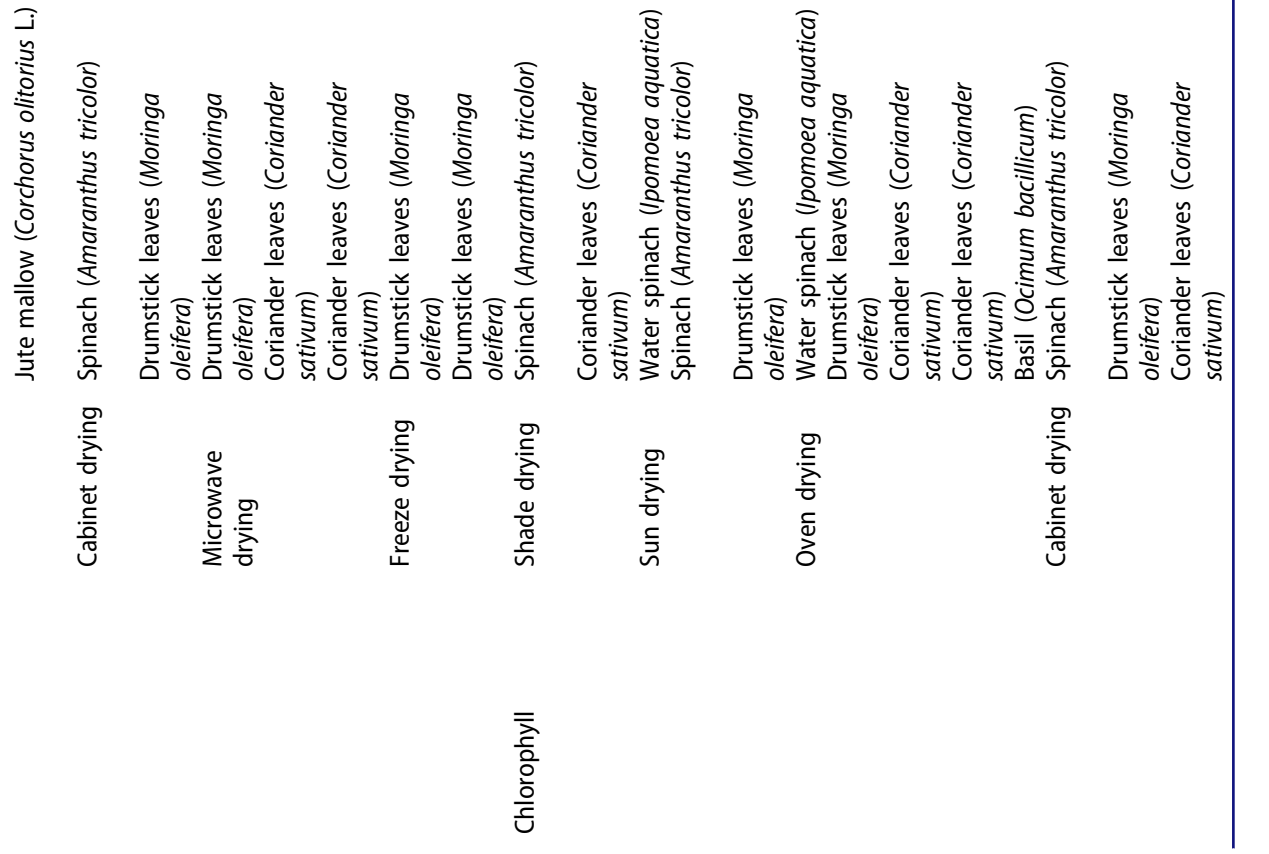




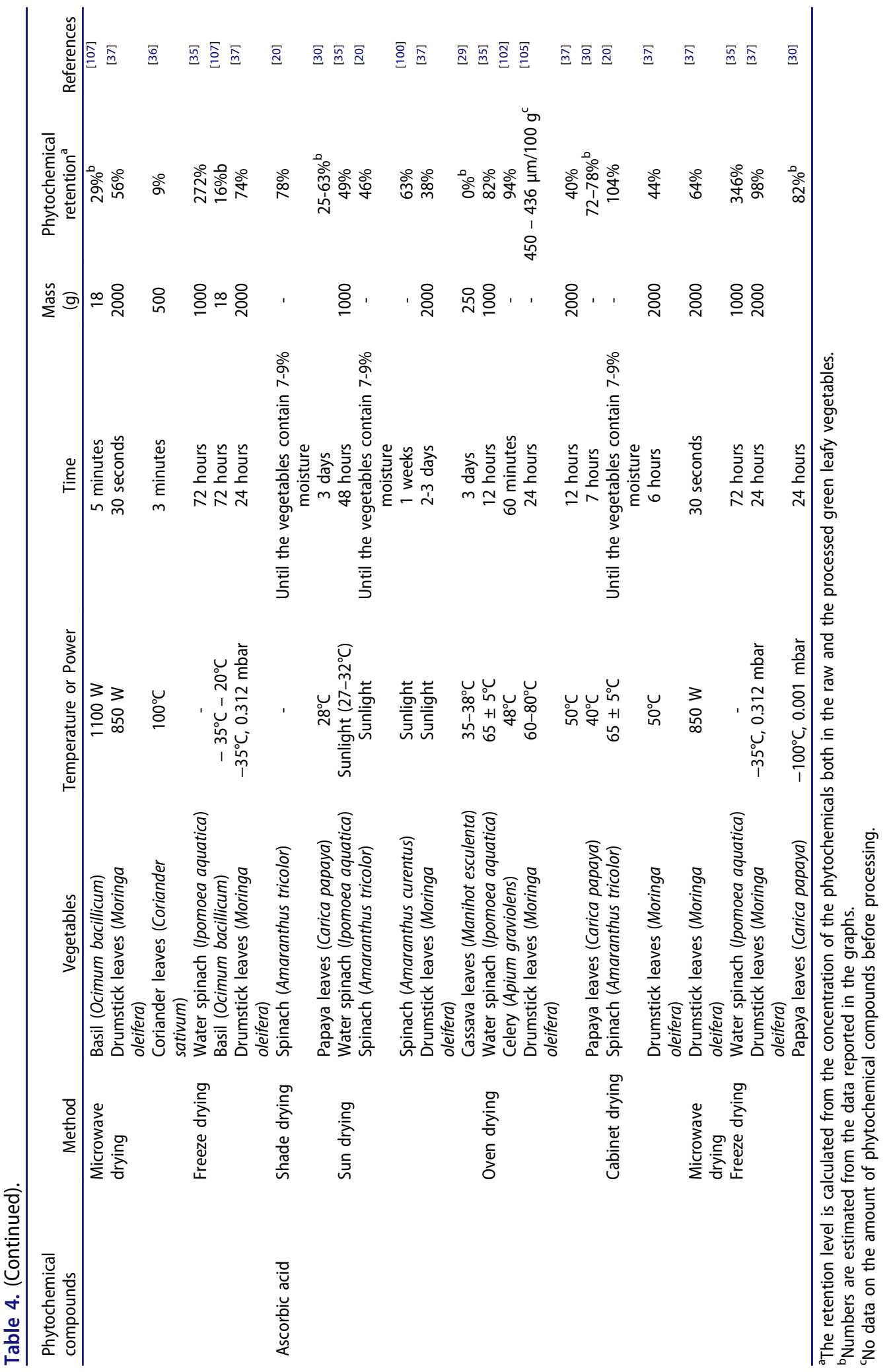


total polyphenol, carotenoid, chlorophyll, and ascorbic acid. Cabinet tray drying was also reported to decrease total polyphenol and flavonoid in spinach and in coriander leaves. ${ }^{\text {[26] }}$

The retention of chlorophyll A and B is higher during cabinet drying than oven drying, thus cabinet drying produces the dark green color of the powder, which consumers prefer to choose. It is mostly due to forced convection of heated air in the cabinet dryer which can reduce the drying time. ${ }^{[37]}$

Carotenoids retention in vegetables was higher after oven drying than after sun drying because the closed condition in oven drying mitigates the risk of photooxidation. ${ }^{[18]}$ Compared to shade drying, the decrease of total polyphenol, carotenoid, and chlorophyll in coriander leaves ${ }^{[36]}$ and $\beta$-carotene of black nightshade and jute mallow leaves ${ }^{[61]}$ after oven drying was higher, which relate to the imposed thermal load. High drying temperature needs to be avoided to mitigate trans-cis isomerization of $\beta$-carotene and lutein. The provitamin activity of the cis- form of carotenoid is lower than the trans- form. ${ }^{[37,61,79]}$

Drying at $60^{\circ} \mathrm{C}$ decreased flavonoid content in kenikir (Cosmos caudatus) leaves because the increase of flavonoid degrading enzyme activity such as polyphenoloxidase enzyme. ${ }^{[104]}$ However, the enzyme activity could be reduced by drying at temperatures higher than $70^{\circ} \mathrm{C}$. The content of phytochemical compounds in vegetables can also have further losses during storage. ${ }^{[102]}$ Grinding could increase the surface area of the dried product that leads to further losses through autooxidation. Therefore, dried or powdered vegetables must be protected from air and light. ${ }^{[37]}$

Wangcharoen \& Gomolmanee ${ }^{[103]}$ reported that drying of drumstick leaves at $50^{\circ} \mathrm{C}$ decreases total phenolic contents in vegetables. However, when drying was performed at a higher temperature $\left(100^{\circ} \mathrm{C}\right)$, phenolic contents initially decrease then increase again in the later stage. The fluctuation of total phenolic contents could be due to the formation of new antioxidant compounds of non-enzymatic browning and due to thermal degradation of insoluble and bound phenolic compounds that occurs at high temperature. Raja et al. ${ }^{[30]}$ also observed the formation of maillard products formed due to heat treatment, which increased total phenolic contents in papaya leaves between $6 \%$ and $64 \%$. Similarly, Negi \& Roy $^{[20]}$ reported that drying could increase carotenoid and vitamin $\mathrm{C}$ in spinach. This relates to the increase of solid fraction, thus concentrating the phytochemical compounds. ${ }^{[26]}$

Table 4 shows that most of the phytochemical compounds in vegetables decreased during microwave drying ranging between $36 \%$ and $91 \%$, which was more pronounced than that of oven-, freeze-, or cabinet drying. ${ }^{[36,37,107]}$ This might be due to the imposed higher temperature during microwave drying than the other drying methods. Dev et al. ${ }^{[111]}$ also reported that the color change of drumstick leaves was more severe after microwave drying than that of oven drying. Retention of chlorophyll was however higher after microwave drying than after air drying. The degradation of chlorophyll pigment to pheophytin is shown by color transformation from bright green to olive brown. The formation of pheophytin was affected by the liberation of plant acid compounds and the release of chlorophyll from protein complex. ${ }^{[107]}$ Divya et al. ${ }^{[106]}$ found that microwave drying increased carotenoid in coriander leaves ranging from about $35 \%$ to $40 \%$. This is due to heating that could liberate carotenoid bound to membranes and other pigments, such as chlorophyll. This study found no trans-cis isomerization of $\beta$-carotene during microwave drying.

Lyophilization or freeze drying is a dehydration process that involves freezing then sublimation of ice. Freeze drying is slower and more energy intensive than another conventional drying. ${ }^{[92,112]}$ Freeze drying was reported to decrease total polyphenol, 
carotenoid, chlorophyll, and ascorbic acid in drumstick leaves. ${ }^{[37}$ Other studies also reported the decrease of ascorbic acid in papaya leaves and chlorophyll in basil. ${ }^{[79,107]}$ Formation of ice crystal can damage cell walls and release oxidative- and hydrolyticenzymes, which degrade phytochemicals such as phenolic compounds. ${ }^{[30]}$

Compared to other drying methods, freeze drying remains the best method to retain trans-lutein, trans-luteoxanthin, trans- $\beta$-carotene, total carotenoid, $\alpha$-tocopherol, ascorbic acid, chlorophyll A, and chlorophyll B. ${ }^{[37]}$ Increase of total phenolic contents in papaya leaves, and chlorophyll and ascorbic acid in water spinach have also been reported. ${ }^{[30,35]}$ It is believed that the use of low temperature during freeze-drying prevents thermal degradation of these heat sensitive compounds. ${ }^{[10]}$ Furthermore, the formation of ice crystals can rupture cell walls, thus allowing the release of cellular components, which consequently improves extractability. ${ }^{[97]}$

\section{Microwave cooking}

Water is often added during microwave cooking of vegetables. This may lead to leaching of water-soluble phytochemical compounds. ${ }^{[67,69]}$ Microwave cooking has been reported to decrease chlorophyll contents in spinach ${ }^{[46]}$ and tatsoi. ${ }^{[73]}$ Induced by heat, the removal of magnesium or carbomethoxy group from chlorophylls may occur to form pheophytins and may subsequently transform to pirochlorophylls. Microwave cooking reduced phenolic compounds in water spinach, ${ }^{[67]}$ drumstick leaves, ${ }^{[13]}$ sweet potato leaves, ${ }^{[17]}$ Chinese mustard ${ }^{[72]}$, tatsoi, ${ }^{[39]}$ and bush sorrel. ${ }^{[74]}$ Microwave cooking also reduced a significant amount of flavonoid, ${ }^{[72]}$ carotenoid, $^{[31]}$ and ascorbic acid ${ }^{[31]}$ in Chinese mustard, and chlorophyll and ascorbic acid in tatsoi. ${ }^{[39]}$ Thermal breakdown, leaching (when water is added during cooking), and oxidation are the responsible mechanisms of phytochemical degradation during microwave cooking. ${ }^{[31,67,69,113]}$

In contrast, increase of total polyphenols in Chinese mustard ${ }^{[31]}$ and drumstick leaves, ${ }^{[71]}$ ascorbic acid in spinach, ${ }^{[80]}$ and flavonoid in drumstick leaves have been reported. ${ }^{[80]}$ Breakdown of cell walls and complex phenolic compounds during heating may increase the availability of these phytochemical compounds. ${ }^{[71,74,80,114]}$

\section{Pressure cooking}

Employing high pressure enables cooking at temperatures higher than the normal boiling point of water. Heat sensitive phytochemicals are better retained because cooking time can be considerably reduced. However, water-soluble phytochemical compounds may be leached due to the presence of added water during pressure-cooking. ${ }^{[67]}$ Veda et al. ${ }^{[33]}$ reported that pressure-cooking at 15 psi for 10 min decreased carotenoid in spinach, in drumstick leaves, and in coriander leaves. Pressure-cooking also decreased carotenoid and ascorbic acid content in Chinese mustard by about $13 \%$ and $69 \%$, respectively ${ }^{[31]}$, which likely relates to leaching, oxidation, and formation of cis isomers from all trans- $\beta$-carotene. ${ }^{[33]}$

Pressure cooking, however, has been reported to increase total phenolic concentration in Chinese mustard ${ }^{[31]}$ and in drumstick leaves. ${ }^{[115]}$ This is likely due to the softening of vegetable matrices that improve extractability, the liberation of phenolic compounds from pectin or cellulose networks, the formation of secondary plant metabolites, inactivation of 
oxidative enzymes (e.g. polyphenol oxidase), and release of active aglycones from flavonoid conjugates during heating. ${ }^{[67,114,115]}$

\section{Frying}

Frying is performed by increasing the surface temperature of food and then vaporizing a proportion of water. ${ }^{[112]}$ Based on the media for heat transfer, frying can be categorized into frying in oil (stir frying and deep frying) and frying with the addition of water such as stewing and sauteing. ${ }^{[32]}$ Frying is usually applied at high temperatures to maximize the heat transfer.

Frying generally decreased carotenoid content in basil leaves, drumstick leaves, coriander leaves, sweet potato leaves, and pak choi (Table 5). The decrease of $\beta$-carotene in vegetables was reported to be higher in deep fat frying than in shallow contact frying. ${ }^{[33]}$ This may relate to degradation or isomerization of carotenoids, the release of carotenoids to oil, and cell disruption during frying. ${ }^{[65,79]}$ Moreover, the release of carotenoid into oil is affected by the amount of oil, frying time, location, and chemical and physical structure of carotenoid. ${ }^{[32]}$

Frying, especially stir-frying, could increase the availability of $\beta$-carotene in water spinach and spinach. ${ }^{[33]}$ The presence of oil during frying may improve the bioaccessibility of $\beta$ carotene and the loosening of food matrices facilitates carotenoid absorption. ${ }^{[1,32,33]}$ Sun et al. ${ }^{[17]}$ found a $16 \%$ reduction of total phenolic concentration in sweet potato leaves due to the breakdown of phenolic compounds during processing. Frying also decreased phenolic compounds in spinach by $17 \%$, bush sorrel by $29-39 \%$, and tatsoi by $4 \%$ likely due to decomposition and liberation of phenolic compounds. ${ }^{[69,73,74]}$ On the contrary, frying has been found to increase considerably the total polyphenol and flavonoid contents in drumstick leaves, spinach, water spinach, and Chinese mustard and, to a lesser degree, increased ascorbic acid availability. Previous studies suggested that the apparent increase of these phytochemical compounds can be related to the breakdown of the cell wall and softening vegetable tissues, thus liberating the phytochemical compounds and making it more accessible. Other mechanisms include inactivation of oxidative enzymes, thus minimizing the risk of the enzyme rendering phytochemicals into, e.g. its inactive form. ${ }^{[3,68,73,114,116]}$

\section{Conclusion}

Changes of phytochemical compounds in vegetables during cooking/processing are influenced by various factors such as characteristics of the compounds, type of vegetables, and processing methods. Loss of phytochemical compounds during blanching, boiling, microwave cooking, and pressure cooking of green leafy vegetables are often found related to leaching and thermal degradation. Significant losses during frying and drying could be due to the thermal degradation, oxidation reaction, and isomerization of phytochemical structures. Steaming can be the most suitable method to retain phytochemical compounds because of the low impact on thermal degradation, oxidation reaction, and leaching of water-soluble phytochemical compounds, such as polyphenols and ascorbic acid. Increase the bioavailability of phytochemical compounds in vegetables during processing is due to the breakdown of complex bound, cell wall disruption, and inactivation of oxidation enzymes. Processing should therefore be optimized to minimize the loss of phytochemical compounds. 


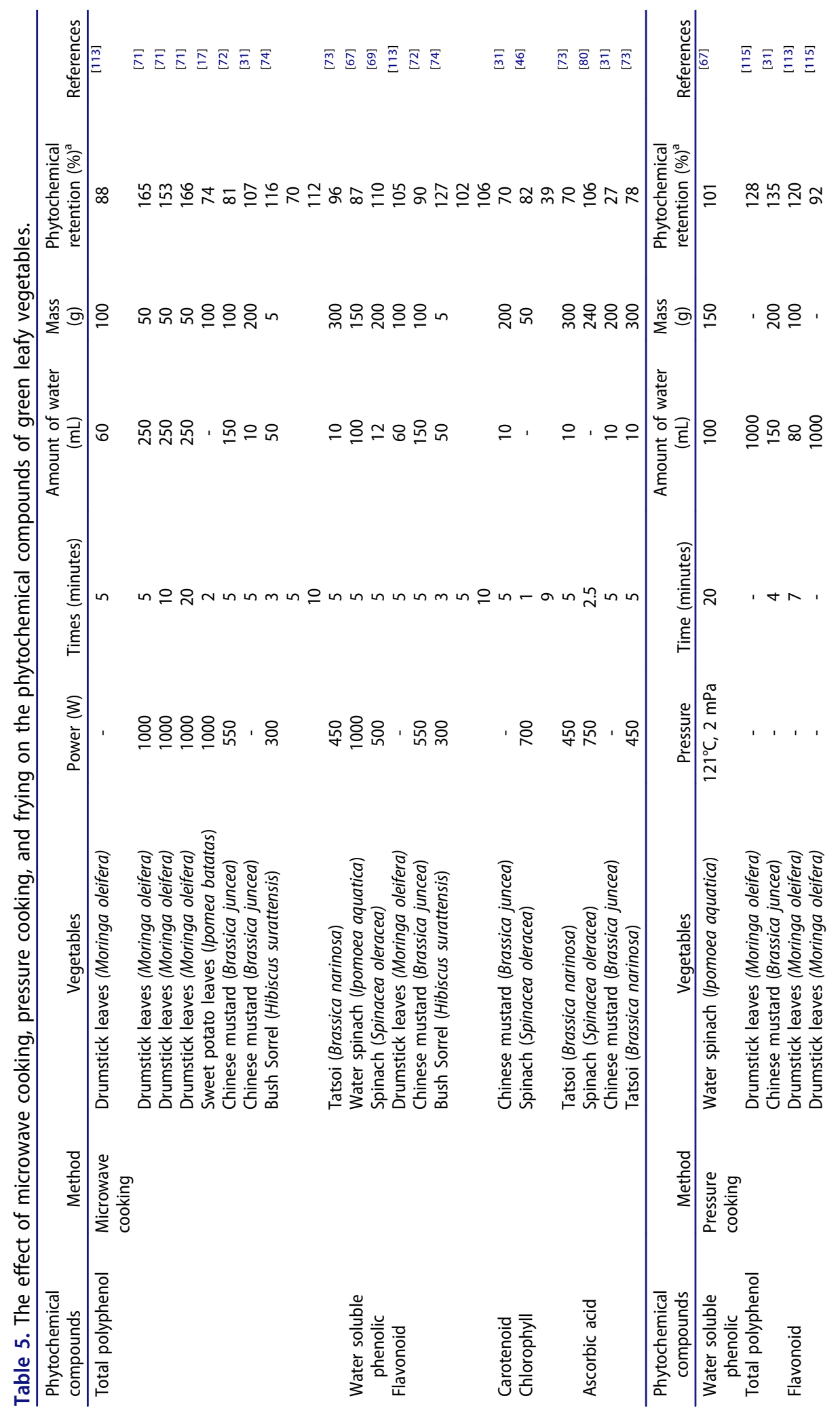


FOOD REVIEWS INTERNATIONAL

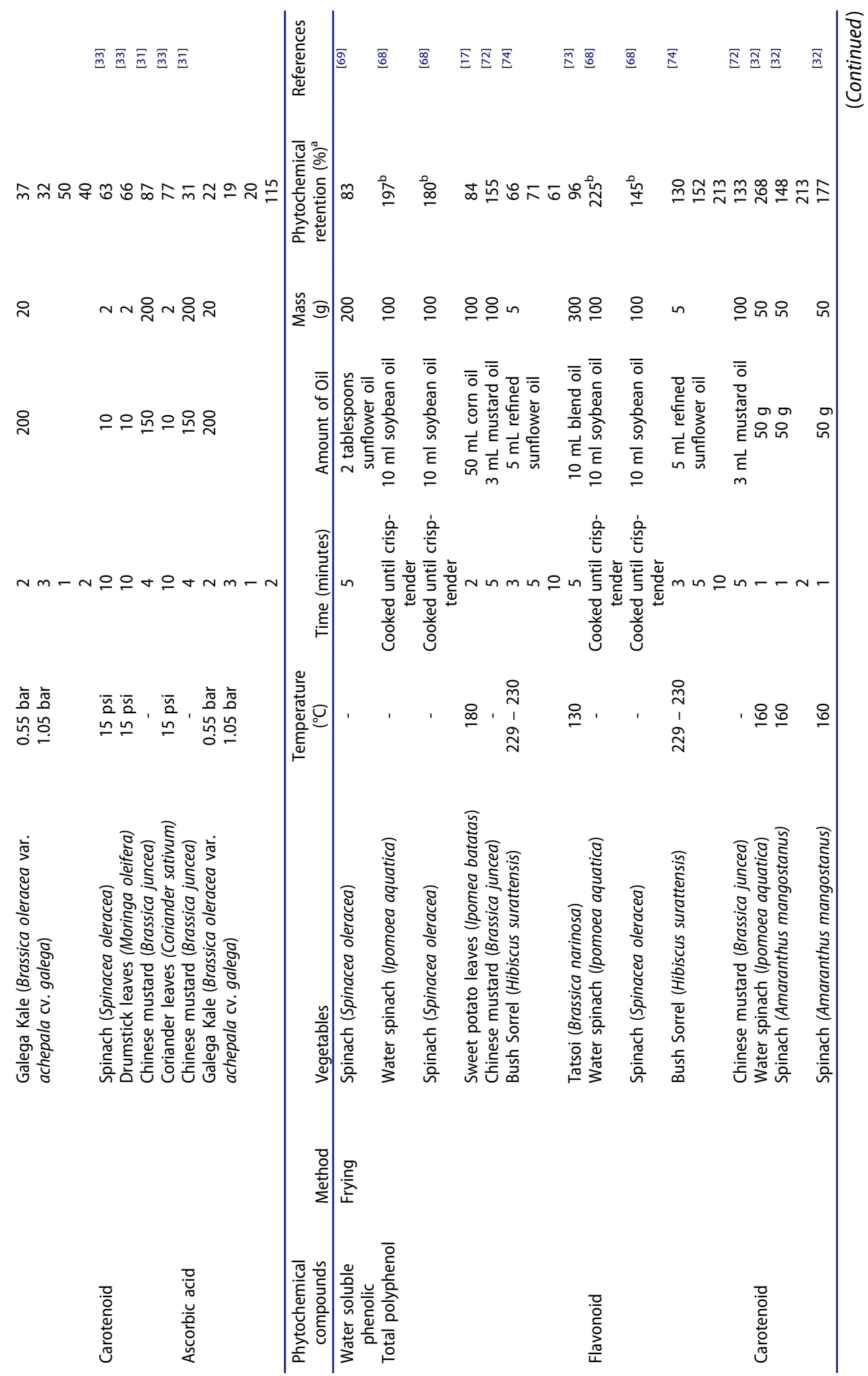




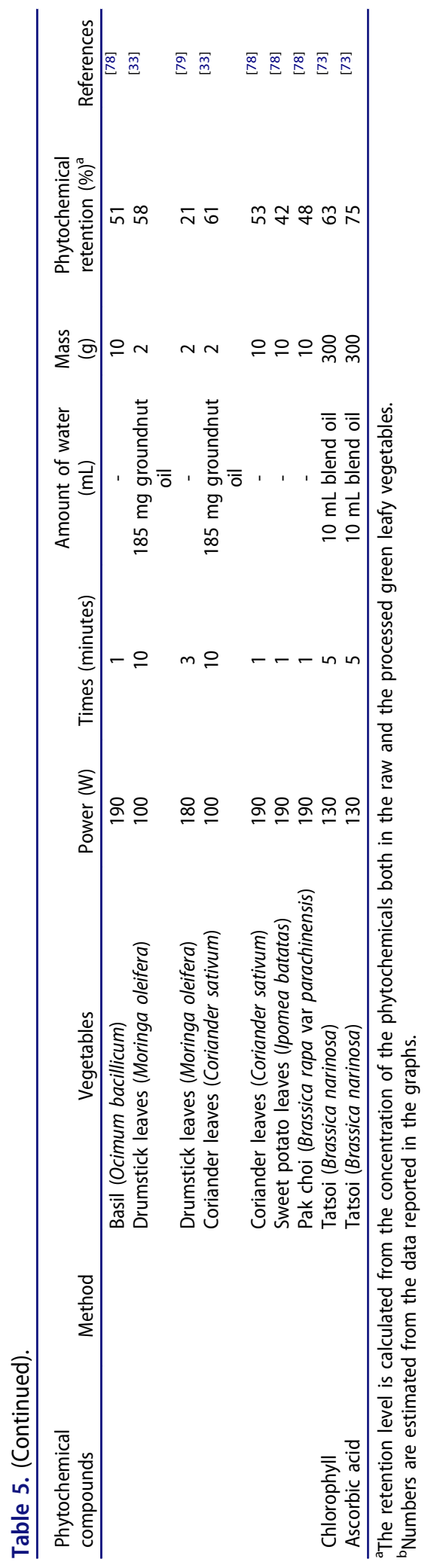




\section{Declarations of Interest}

This research did not receive any specific grant from funding agencies in the public, commercial, or not-for-profit sectors.

\section{References}

[1] Ebert, A. W.;. Promotion of Indigenous Vegetables in Asia: Conservation and Use of Selected Crops in Indonesia, the Philippines, and Taiwan. Acta Hortic. 2011, 918(918), 397-403. DOI: 10.17660/ActaHortic.2011.918.51.

[2] Olayinka, O. O.;. Antioxidant Contents (Vitamin C) of Raw and Blanched Different Fresh Vegetable Samples. Food Nutr. Sci. 2012, 3(1), 18-21. DOI: 10.4236/fns.2012.31004.

[3] Duma, M.; Alsina, I.; Zeipina, S.; Lepse, L.; Dubova, L. Leaf Vegetables as Source of Phytochemicals. In Foodbalt 2014: 9th Baltic conference on food science and technology "Food for consumer well-being"; LLU: Jelgava, 2014; pp 262-265.

[4] Williams, D. J.; Edwards, D.; Hamernig, I.; Jian, L.; James, A. P.; Johnson, S. K.; Tapsell, L. C. Vegetables Containing Phytochemicals with Potential Anti-Obesity Properties: A Review. Food Res. Int. 2013, 52(1), 323-333. DOI: 10.1016/j.foodres.2013.03.015.

[5] Perdana, J.; den Besten, H. M. W.; Aryani, D. C.; Kutahya, O.; Fox, M. B.; Kleerebezem, M.; Boom, R. M.; Schutyser, M. A. I. Inactivation of Lactobacillus plantarum WCFS1 during Spray Drying and Storage Assessed with Complementary Viability Determination Methods. Food Res. Int. 2014, 64, 212-217. DOI: 10.1016/j.foodres.2014.06.029.

[6] Do, T. N.; Hwang, E. Effects of Different Cooking Methods on Bioactive Compound Content and Antioxidant Activity of Water Spinach (Ipomoea aquatica). Food Sci. Biotechnol. 2015, 24(3), 799-806. DOI: 10.1007/s10068-015-0104-1.

[7] Zhao, C.; Liu, Y.; Lai, S.; Cao, H.; Guan, Y.; San Cheang, W.; Liu, B.; Zhao, K.; Miao, S.; Riviere, C.; et al. Effects of Domestic Cooking Process on the Chemical and Biological Properties of Dietary Phytochemicals. Trends Food Sci. Technol.2019, 85(2017), 55-66. DOI: 10.1016/j.tifs.2019.01.004.

[8] Sivakumar, D.; Chen, L.; Sultanbawa, Y. A Comprehensive Review on Beneficial Dietary Phytochemicals in Common Traditional Southern African Leafy Vegetables. Food Sci. Nutr. 2018, 6(4), 714-727. DOI: 10.1002/fsn3.643.

[9] Ribas-Agustí, A.; Martín-Belloso, O.; Soliva-Fortuny, R.; Elez-Martínez, P. Food Processing Strategies to Enhance Phenolic Compounds Bioaccessibility and Bioavailability in Plant-Based Foods. Crit. Rev. Food Sci. Nutr. 2018, 58(15), 2531-2548. DOI: 10.1080/ 10408398.2017.1331200.

[10] Sensoy, I.; Mahallesi, U.; Bulvari, D. A Review on the Relationship between Food Structure, Processing, and Bioavailability. Crit. Rev. Food Sci. Nutr. 2013, 54(7), 37-41. DOI: 10.1080/ 10408398.2011.619016.

[11] Barba, F. J.; Mariutti, L. R. B.; Bragagnolo, N.; Mercadante, A. Z.; Barbosa-Cánovas, G. V.; Orlien, V. Bioaccessibility of Bioactive Compounds from Fruits and Vegetables after Thermal and Nonthermal Processing. Trends Food Sci. Technol. 2017, 67, 195-206. DOI: 10.1016/j.tifs.2017.07.006.

[12] Shahidi, F.; Peng, H. Bioaccessibility and Bioavailability of Phenolic Compounds. J. Food Bioact. 2018, 4, 11-68. DOI: 10.31665/JFB.2018.4162.

[13] Davey, M. W.; Montagu, M. V.; Inze, D.; Sanmartin, M.; Kanellis, A.; Smirnoff, N.; Benzie, I. J.; Strain, J. J.; Favell, D.; Fletcher, J. Review Plant L-Ascorbic Acid: Chemistry, Function, Metabolism, Bioavailability and Effects of Processing. J. Sci. Food Agric. 2000, 80, 825-860. DOI: 10.1002/(SICI)1097-0010(20000515)80:7<825::AID-JSFA598>3.0.CO;2-6.

[14] Thilakarathna, S. H.; Rupasinghe, H. P. V. Flavonoid Bioavailability and Attempts for Bioavailability Enhancement. Nutrients. 2013, 5, 3367-3387. DOI: 10.3390/nu5093367. 
[15] Corte-Real, J.; Bohn, T. Interaction of Divalent Minerals with Liposoluble Nutrients and Phytochemicals during Digestion and Influences on Their Bioavailability - A Review. Food Chem. 2018, 252, 285-293. DOI: 10.1016/j.foodchem.2018.01.113.

[16] Zhang, Y.; Gan, R.; Li, S.; Zhou, Y.; Li, A.; Xu, D. Antioxidant Phytochemicals for the Prevention and Treatment of Chronic Diseases. Molecules. 2015, 20, 21138-21156. DOI: 10.3390/molecules201219753.

[17] Sun, H.; Mu, T.; Xi, L.; Song, Z. Effects of Domestic Cooking Methods on Polyphenols and Antioxidant Activity of Sweet Potato Leaves. J. Agric. Food Chem. 2014, 62, 8982-8989. DOI: $10.1021 /$ jf502328d.

[18] Djuikwo, V. N.; Ejoh, R. A.; Gouado, I.; Mbofung, C. M.; Tanumihardjo, S. A. Determination of Major Carotenoids in Processed Tropical Leafy Vegetables Indigenous to Africa. Food Nutr. Sci. 2011, 2, 793-802. DOI: 10.4236/fns.2011.28109.

[19] Hsu, C.; Chao, P.; Hu, S.; Yang, C. The Antioxidant and Free Radical Scavenging Activities of Chlorophylls and Pheophytins. Food Nutr. Sci. 2013, 4, 1-8. DOI: 10.4236/ fns.2013.48A001.

[20] Negi, P. S.; Roy, S. K. Effect of Blanching and Drying Methods on $\beta$-carotene, Ascorbic Acid and Chlorophyll Retention of Leafy Vegetables. Food Sci. Technol. 2000, 33(4), 295-298. DOI: 10.1006/fstl.2000.0659.

[21] Shashank, K.; Abhay, K. Chemistry and Biological Activities of Flavonoids: An Overview. Sci. World J. 2013, 4(2), 32-48.

[22] Nugrahedi, P. Y.; Verkerk, R.; Widianarko, B.; Dekker, M. A Mechanistic Perspective on Process-Induced Changes in Glucosinolate Content in Brassica Vegetables: A Review. Crit. Rev. Food Sci. Nutr. 2015, 55(6), 823-838. DOI: 10.1080/10408398.2012.688076.

[23] Durazzo, A.; Lucarini, M.; Souto, E. B.; Cicala, C.; Caiazzo, E.; Izzo, A. A.; Novellino, E.; Santini, A. Polyphenols: A Concise Overview on the Chemistry, Occurrence, and Human Health. Phyther. Res. 2019, 33(9), 2221-2243. DOI: 10.1002/ptr.6419.

[24] Balasundram, N.; Sundram, K.; Samman, S. Phenolic Compounds in Plants and Agri-Industrial by-Products: Antioxidant Activity, Occurrence, and Potential Uses. Food Chem. 2006, 99(1), 191-203. DOI: 10.1016/j.foodchem.2005.07.042.

[25] Liu, R. H.;. Health Benefits of Fruit and Vegetables are from Additive and Synergistic Combinations of Phytochemicals. Am. J. Clin. Nutr. 2003, 78, 517-520. DOI: 10.1093/ ajcn/78.3.517S.

[26] Meena, S.; Agrawal, M.; Agrawal, K. Effect of Blanching and Drying on Antioxidants and Antioxidant Activity of Selected Green Leafy Vegetables. Int. J. Sci. Res. 2016, 5(10), 1811-1814.

[27] Nartnampong, A.; Kittiwongsunthon, W.; Porasuphatana, S. Blanching Process Increases Health Promoting Phytochemicals in Green Leafy Thai Vegetables. Int. Food Res. J. 2016, 23 (6), 2426-2435.

[28] Yao, Y.; Sang, W.; Zhou, M.; Ren, G. Phenolic Composition and Antioxidant Activities of 11 Celery Cultivars. J. Food Sci. 2010, 75(1), 9-13. DOI: 10.1111/j.1750-3841.2009.01392.x.

[29] Zoro, A. F.; Zoué, L. T.; Adom, N. J.; Niamké, S. L.; Effect of Sun Drying on Nutritive and Antioxidant Properties of Leafy Vegetables Consumed in Western Côte D'Ivoire. African J. Sci. Res. 2015, 54, 24-31. DOI:10.11648/j.jfns.20150301.14.

[30] Raja, K. S.; Taip, F. S.; Azmi, M. M. Z.; Shishir, M. R. I. Effect of Pre-Treatment and Different Drying Methods on the Physicochemical Properties of Carica papaya L. Leaf Powder. J. Saudi Soc. Agric. Sci. 2017. DOI: 10.1016/j.jssas.2017.04.001.

[31] Bembem, K.; Sadana, B.; Bains, K. Effect of Domestic Cooking Methods on the Nutritive and Antioxidative Components of Mustard Leaves (Brassica juncea). Int. J. Food, Agric. Vet. Sci. 2014, 4(1), 24-31.

[32] Kidmose, U.; Yang, R. Y.; Thilsted, S. H.; Christensen, L. P.; Brandt, K. Content of Carotenoids in Commonly Consumed Asian Vegetables and Stability and Extractability during Frying. J. Food Compos. Anal. 2006, 19(6-7), 562-571. DOI: 10.1016/j.jfca.2006.01.011.

[33] Veda, S.; Platel, K.; Srinivasan, K. Enhanced Bioaccessibility of $\beta$-Carotene from YellowOrange Vegetables and Green Leafy Vegetables by Domestic Heat Processing. Int. J. Food Sci. Technol. 2010, 45(10), 2201-2207. DOI: 10.1111/j.1365-2621.2010.02385.x. 
[34] Ahamad, M. N.; Saleemullah, M.; Shah, H. U. Determination of Beta Carotene Content in Fresh Vegetables Using High Performance Liquid Chromatography. Sarhad J. Agric. 2007, 23(3), 767-770.

[35] Shin, L. E. R.; Zzaman, W.; Kuang, Y. T.; Bhat, R. Influence of Dehydration Techniques on Physicochemical, Antioxidant and Microbial Qualities of Ipomoea aquatica Forsk: An Underutilized Green Leafy Vegetable. J. Food Process. Preserv. 2015, 39(6), 1118-1124. DOI: $10.1111 /$ jfpp.12326.

[36] Kamel, S. M.; Thabet, H. A.; Algadi, E. A. Influence of Drying Process on the Functional Properties of Some Plants. Chem. Mater. Res. 2013, 3(7), 1-9.

[37] Saini, R. K.; Shetty, N. P.; Prakash, M.; Giridhar, P. Effect of Dehydration Methods on Retention of Carotenoids, Tocopherols, Ascorbic Acid and Antioxidant Activity in Moringa oleifera Leaves and Preparation of a RTE Product. J. Food Sci. Technol. 2014, 51(9), 2176-2182. DOI: 10.1007/s13197-014-1264-3.

[38] Combs, G. F.; McClung, P.; Vitamin, J. C. Chapter 10 - In the Vitamins Fundamental Aspects in Nutrition and Health. London: Academic Press, 2017; pp 267-295. doi: 10.1016/B9780-12-802965-7.00010-1.

[39] Yao, Y.; Ren, G. Effect of Thermal Treatment on Phenolic Composition and Antioxidant Activities of Two Celery Cultivars. Food Sci. Technol. 2011, 44(1), 181-185. DOI: 10.1016/j. lwt.2010.07.001.

[40] Palafox-Carlos, H.; Ayala-Zavala, J. F.; González-Aguilar, G. A. The Role of Dietary Fiber in the Bioaccessibility and Bioavailability of Fruit and Vegetable Antioxidants. J. Food Sci. 2011, 76(1), 6-15. DOI: 10.1111/j.1750-3841.2010.01957.x.

[41] Cory, H.; Passarelli, S.; Szeto, J.; Tamez, M.; Mattei, J. The Role of Polyphenols in Human Health and Food Systems: A Mini-Review. Front. Nutr. 2018, 5, 1-9. DOI: 10.3389/ fnut.2018.00087.

[42] Schwartz, S. J.; Elbe, J. H. V.; Giusti, M. M. Colorants. In Fennema's Food Chemistry; Damodaran, S., Parkin, K.L., Fennema, O.R., Eds.; CRC Press: New York, 2008; pp 571-638.

[43] Yahia, E. M.; Ornelas-Paz, J. Chemistry, Stability, and Biological Actions of Carotenoids. In Fruit and Vegetable Phytochemicals: Chemistry, Nutritional Value, and Stability. Rosa, L. A. de la, Alvarez-Parrilla, E., Gustavo A. Gonzalez-Aguilar, Eds.; Wiley-Blackwell: Oxford, 2009; pp 177-222. https://doi.org/10.1002/9780813809397.

[44] Stahl, W.; Sies, H. Antioxidant Activity of Carotenoids. Mol. Aspects Med. 2003, 24(6), 345-351. DOI: 10.1016/S0098-2997(03)00030-X.

[45] Khalid, M.; Rahman, S.; Bilal, M.; Iqbal, H. M. N.; Huang, D. Biosynthesis and Biomedical of Carotenoids with Special Reference to Human-Related Applications. Biocatal. Agric. Biotechnol. 2019, 17, 399-407. DOI: 10.1016/j.bcab.2018.11.027.

[46] Teng, S. S.; Chen, B. H. Formation of Pyrochlorophylls and Their Derivatives in Spinach Leaves during Heating. Food Chem. 1999, 65(3), 367-373. DOI: 10.1016/S0308-8146(98) 00237-4.

[47] Chao, P. Y.; Huang, M. Y.; Huang, W. D.; Lin, K. H.; Chen, S. Y.; Yang, C. M.; Study of Chlorophyll-Related Compounds from Dietary Spinach in Human Blood. Not. Bot. Horti Agrobot. Cluj-Napoca. 2018, 462, 309-316. DOI:10.15835/nbha46210918.

[48] Khalid, M.; Saeed-ur-Rahman,; Bilal, M.; Iqbal, H. M. N.; Huang, D. Biosynthesis and Biomedical Perspectives of Carotenoids with Special Reference to Human Health-Related Applications. Biocatal. Agric. Biotechnol. 2019, 17, 399-407. DOI: 10.1016/j.bcab.2018.11.027.

[49] Vaňková, K.; Marková, I.; Jašprová, J.; Dvořák, A.; Subhanová, I.; Zelenka, J.; Novosádová, I.; Rasl, J.; Vomastek, T.; Sobotka, R.; et al. Chlorophyll-Mediated Changes in the Redox Status of Pancreatic Cancer Cells are Associated with Its Anticancer Effects. Oxid. Med. Cell. Longev. 2018. DOI: $10.1155 / 2018 / 4069167$.

[50] Ottaway, P. B.;. Fortification of Beverages with Vitamins and Minerals. In Functional and Speciality Beverage Technology; Paquin, P., Ed.; Woodhead Publishing Limited: Cambridge, 2009; pp 71-90. 
[51] Chambial, S.; Dwivedi, S.; Shukla, K. K.; John, P. J.; Sharma, P. Vitamin C in Disease Prevention and Cure: An Overview. Indian J. Clin. Biochem. 2013, 28(4), 314-328. DOI: 10.1007/s12291-013-0375-3.

[52] Natella, F.; Maldini, M.; Leoni, G.; Scaccini, C. Glucosinolates Redox Activities: Can They Act as Antioxidants? Food Chem. 2014, 149, 226-232. DOI: 10.1016/j.foodchem.2013.10.134.

[53] Vig, A. P.; Rampal, G.; Thind, T. S.; Arora, S. Bio-Protective Effects of Glucosinolates - A Review. Food Sci. Technol. 2009, 42(10), 1561-1572. DOI: 10.1016/j.lwt.2009.05.023.

[54] Mitsiogianni, M.; Koutsidis, G.; Mavroudis, N.; Trafalis, D. T.; Botaitis, S.; Franco, R.; Zoumpourlis, V.; Amery, T.; Galanis, A.; Pappa, A.;; et al. The Role of Isothiocyanates as Cancer Anti-Melanoma Agents. Antioxidants. 2019, 8(106), 1-35.

[55] Vanduchova, A.; Anzenbacher, P.; Anzenbacherova, E. Isothiocyanate from Broccoli, Sulforaphane, and Its Properties. J. Med. Food. 2018, 22(2), 1-6. DOI: 10.1089/jmf.2018.0024.

[56] Lafarga, T.; Bobo, G.; Viñas, I.; Collazo, C.; Aguiló-Aguayo, I. Effects of Thermal and Non-Thermal Processing of Cruciferous Vegetables on Glucosinolates and Its Derived Forms. J. Food Sci. Technol. 2018, 55(6), 1973-1981. DOI: 10.1007/s13197-018-3153-7.

[57] Oliviero, T.; Verkerk, R.; Dekker, M. Isothiocyanates from Brassica Vegetables-effects of Processing, Cooking, Mastication, and Digestion. Mol. Nutr. Food Res. 2018, 62(18), 1-30. DOI: $10.1002 / \mathrm{mnfr} .201701069$.

[58] Corcuera, J. I. R.; Cavalieri, R. P.; Powers, J. R. Blanching of Foods. In Encyclopedia of Agricultural, Food, and Biological Engineering; Heldman, D.R., Moraru, C.I., Eds.; Marcel Dekker, Inc.: New York, 2004; pp 1-5. DOI: 10.1081/E-EAFE-120030417.

[59] Kaiser, A.; Kammerer, D. R.; Carle, R. Impact of Blanching on Polyphenol Stability and Antioxidant Capacity of Innovative Coriander (Coriandrum sativum L.) Pastes. Food Chem. 2013, 140(2013), 332-339. DOI: 10.1016/j.foodchem.2013.02.077.

[60] Amin, I.; Wee, Y. L. Effect of Different Blanching Times on Antioxidant Properties in Selected Cruciferous Vegetables. J. Sci. Food Agric. 2005, 85(13), 2314-2320. DOI: 10.1002/jsfa.2261.

[61] Traoré, K.; Parkouda, C.; Savadogo, A.; Ba, F.; Kamga, R.; Traore, Y. Effect of Processing Methods on the Nutritional Content of Three Traditional Vegetables Leaves: Amaranth, Black Nightshade, and Jute Mallow. Food Sci. Nutr. 2017, 5(6), 1139-1144. DOI: 10.1002/ fsn3.504.

[62] Salau, B.; Odufuwa, K.; Adeosun, C.; Atunnise, A.; Blanching and Juicing Effect on Flavonoids Contents in Commonly Consumed Leafy Vegetables in South West Nigeria. Int. J. Biochem. Res. Rev. 2015, 53, 207-213. DOI:10.9734/IJBCRR/2015/14230.

[63] Waldron, K. W.; Smith, A. C.; Parr, A. J.; Ng, A.; Parker, M. L. New Approaches to Understanding and Controlling Cell Separation in Relation to Fruit and Vegetable Texture. Trends Food Sci. Technol. 1997, 8(7), 213-221. DOI: 10.1016/S0924-2244(97)01052-2.

[64] Miglio, C. C.; Chiavaro, E.; Visconti, A.; Fodliano, V.; Pellegrini, N.; Fogliano, V.; Pellegrini, N. Effects of Different Cooking Methods on Nutritional and Physiochemical Characteristics of Selected Vegetables. J. Agric. Food Chem. 2008, 56(1), 139-147. DOI: 10.1021/jf072304b.

[65] Kao, F. J.; Chiu, Y. S.; Chiang, W. D. Effect of Water Cooking on Antioxidant Capacity of Carotenoid-Rich Vegetables in Taiwan. J. Food Drug Anal. 2014, 22(2), 202-209. DOI: 10.1016/j.jfda.2013.09.010.

[66] Moyo, S. M.; Serem, J. C.; Bester, M. J.; Mavumengwana, V.; Kayitesi, E. Influence of Boiling and Subsequent Phases of Digestion on the Phenolic Con- Tent, Bioaccessibility, and Bioactivity of Bidens pilosa (Blackjack) Leafy Vegetable. Food Chem. 2020, 311. DOI: 10.1016/j.foodchem.2019.126023.

[67] Ng, Z. X.; Chai, J. W.; Kuppusamy, U. R. Customized Cooking Method Improves Total Antioxidant Activity in Selected Vegetables. Int. J. Food Sci. Nutr. 2011, 62(2), 158-163. DOI: $10.3109 / 09637486.2010 .526931$.

[68] Hossain, A.; Khatun, M. A.; Islam, M.; Huque, R. Enhancement of Antioxidant Quality of Green Leafy Vegetables upon Different Cooking Method. Prev. Nutr. Food Sci. 2017, 22(3), 216-222. DOI: 10.3746/pnf.2017.22.3.216. 
[69] Sultana, B.; Anwar, F.; Iqbal, S. Effect of Different Cooking Methods on the Antioxidant Activity of Some Vegetables from Pakistan. Int. J. Food Sci. Technol. 2008, 43(3), 560-567. DOI: $10.1111 /$ j.1365-2621.2006.01504.x.

[70] Lako, J.; Trenerry, V. C.; Wahlqvist, M.; Wattanapenpaiboon, N.; Sotheeswaran, S.; Premier, R. Phytochemical Flavonols, Carotenoids and the Antioxidant Properties of a Wide Selection of Fijian Fruit, Vegetables and Other Readily Available Foods. Food Chem. 2007, 101(4), 1727-1741. DOI: 10.1016/j.foodchem.2006.01.031.

[71] Subramaniam, S.; Rosdi, M. H. B.; Kuppusamy, U. R. Customized Cooking Methods Enhance Antioxidant, Antiglycemic, and Insulin-Like Properties of Momordica charantia and Moringa oleifera. J. Food Qual. 2017, 2017, 1-9. DOI: 10.1155/2017/9561325.

[72] Subudhi, B. B.; Bhoi, A. Antioxidative Effects of Brassica juncea and Moringa oleifera Prepared by Different Processing Methods. J. Food Sci. Technol. 2014, 51(4), 790-794. DOI: 10.1007/s13197-011-0542-6.

[73] Yang, W.; Lu, X.; Zhang, Y.; Qiao, Y. Effect of Cooking Methods on the Health-Promoting Compounds, Antioxidant Activity, and Nitrate of Tatsoi (Brassica rapa L. Ssp. Narinosa). J. Food Process. Preserv. 2019, 43(8), 1-8. DOI: 10.1111/jfpp.14008.

[74] Moorthy, P.; Rajan, M.; Sathyanarayanan, S.; Muniyandi, K.; Sivaraj, D.; Sasidharan, S. P.; Thangaraj, P.; Effect of Different Cooking Methods of Hibiscus surratensis L. Leaf Vegetable on Nutritional, Anti-Nutritional Composition, and Antioxidant Activities. J. Culin. Sci. Technol. 2018, 181, 13-28. DOI:10.1080/15428052.2018.1502110.

[75] Armesto, J.; Gómez-Limia, L.; Carballo, J.; Martínez, S. Effects of Different Cooking Methods on the Antioxidant Capacity and Flavonoid, Organic Acid and Mineral Contents of Galega Kale (Brassica oleracea Var. Acephala Cv. Galega). Int. J. Food Sci. Nutr. 2018, 70(2), 136-149. DOI: 10.1080/09637486.2018.1482530.

[76] Speek, A. J.; Saichua, S. S.; Schreurs, W. H. P. Total Carotenoid and $\beta$-Carotene Contents of Thai Vegetables and the Effect of Processing. Food Chem. 1988, 27, 245-257. DOI: 10.1016/ 0308-8146(88)90010-6.

[77] Miti, V.; Stankov, V.; Dimitrijevi, M.; Cvetkovi, J.; Stojanovi, G. Chemometric Analysis of Chlorophyll A, B and Carotenoid Content in Green Leafy Vegetables. Biol. Nyssana. 2013, 4, 49-55.

[78] Kao, F. J.; Chiu, Y. S.; Tsou, M. J.; Chiang, W. D. Effects of Chinese Domestic Cooking Methods on the Carotenoid Composition of Vegetables in Taiwan. Food Sci. Technol. 2012, 46(2), 485-492. DOI: 10.1016/j.lwt.2011.11.019.

[79] Sriwichai, W.; Collin, M.; Tranbarger, T. J.; Berger, J.; Avallone, S. Improvement of the Content in Bioaccessible Lipophilic Micronutrients in Raw and Processed Drumstick Leaves (Moringa oleifera Lam.). Food Sci. Technol. 2017, 75, 279-285. DOI: 10.1016/j.lwt.2016.09.001.

[80] Hunter, K. J.; Fletcher, J. M. The Antioxidant Activity and Composition of Fresh, Frozen, Jarred and Canned Vegetables. Innov. Food Sci. Emerg. Technol. 2002, 3(4), 399-406. DOI: 10.1016/S1466-8564(02)00048-6.

[81] Delchier, N.; Reich, M.; Renard, C. M. G. C. Impact of Cooking Methods on Folates, Ascorbic Acid and Lutein in Green Beans (Phaseolus vulgaris) and Spinach (Spinacea oleracea). Food Sci. Technol. 2012, 49(2), 197-201. DOI: 10.1016/j.lwt.2012.06.017.

[82] Zaman, W. U.; Akram, M.; Rehman, R. Effect of Temperature Variations during Cooking and Storage on Ascorbic Acid Contents of Vegetables: A Comparative Study. J. Chem. Soc. Pakistan. 2013, 35(1), 1-4.

[83] Fafunso, M.; Bassir, O. Effect of Cooking on the Vitamin C Content of Fresh Leaves and Wilted Leaves. J. Agric. Food Chem. 1976, 24(2), 354-355. DOI: 10.1002/jctb.5000592602.

[84] Adefegha, S. A.; Oboh, G. Enhancement of Total Phenolics and Antioxidant Properties of Some Tropical Green Leafy Vegetables by Steam Cooking. J. Food Process. Preserv. 2011, 35 (5), 615-622. DOI: $10.1111 / \mathrm{j} .1745-4549.2010 .00509$.

[85] Igwemmar, N. C.; Kolawole, S. A.; Imran, I. A. Effect of Heating on Vitamin C Content of Some Selected Vegetables. Int. J. Sci. Technol. Res. 2013, 2(11), 209-212.

[86] Gehse, S.; Knorr, F.; Patzelt, A.; Zastrow, L.; Meinke, M. C.; Lademann, J.; Darvin, M. E. Determination of the Effect of Boiling on the Bioavailability of Carotenoids in Vegetables 
Using Resonance Raman Spectroscopy. Laser Phys. 2018, 28, 10. DOI: 10.1088/1555-6611/ aad1b4.

[87] Zeng, C.;. Effect of Different Cooking Methods on the Vitamin C Content of Selected Vegetables. Nutr. Food Sci. 2013, 43(5), 438-443. DOI: 10.1108/NFS-11-2012-0123.

[88] Le, G. H.; Philippe, F.; Domon, J.; Gillet, F.; Pelloux, J.; Rayon, C. Cell Wall Metabolism in Response to Abiotic Stress. Plants. 2015, 4(1), 112-166. DOI: 10.3390/plants4010112.

[89] Chen, X. D.; Putranto, A. Modeling Drying Processes: A Reaction Engineering Approach; Cambridge University Press: Cambridge, 2013. DOI: 10.1017/CBO9780511997846.

[90] Boateng, E. D.;. Effect of Drying Methods on Nutrient Quality of Basil (Ocimum viride) Leaves Cultivated in Ghana. Int. Food Res. J. 2013, 20(4), 1569-1573.

[91] Joshi, P.; Mehta, D.; Effect of Dehydration on the Nutritive Value of Drumstick Leaves. J. Metabolomics Syst. Biol. 2010, 11, 5-9. DOI:10.1016/S0031-9422(02)00549-6.

[92] Schutyser, M. A. I.; Perdana, J.; Boom, R. M. Single Droplet Drying for Optimal Spray Drying of Enzymes and Probiotics. Trends Food Sci. Technol. 2012, 27(2), 73-82. DOI: 10.1016/j.tifs.2012.05.006.

[93] Perdana, J.; Van der Sman, R. G. M.; Fox, M. B.; Boom, R. M.; Schutyser, M. A. I. Measuring and Modelling of Diffusivities in Carbohydrate-Rich Matrices during Thin Film Drying. J. Food Eng. 2014, 122(1), 38-47. DOI: 10.1016/j.jfoodeng.2013.08.033.

[94] Thirunathan, P.; Arnz, P.; Husny, J.; Gianfrancesco, A.; Perdana, J. Thermogravimetric Analysis for Rapid Assessment of Moisture Diffusivity in Polydisperse Powder and Thin Film Matrices. Food Chem. 2018, 242, 519-526. DOI: 10.1016/j.foodchem.2017.09.089.

[95] Jin, X.; Van Boxtel, A. J. B.; Gerkema, E.; Vergeldt, F. J.; Van As, H.; Van Straten, G.; Boom, R. M.; Van Der Sman, R. G. M. Anomalies in Moisture Transport during Broccoli Drying Monitored by MRI? Faraday Discuss. 2012, 158, 65-75. DOI: 10.1039/c2fd20049j.

[96] Alakali, J. S.; Kucha, C. T.; Rabiu, I. A. Effect of Drying Temperature on the Nutritional Quality of Moringa oleifera Leaves. African J. Food Sci. 2015, 9(7), 395-399. DOI: 10.5897/ AJFS2014.1145.

[97] Chan, E. W. C.; Lim, Y. Y.; Wong, S. K.; Lim, K. K.; Tan, S. P.; Lianto, F. S.; Yong, M. Y. Effects of Different Drying Methods on the Antioxidant Properties of Leaves and Tea of Ginger Species. Food Chem. 2009, 113(1), 166-172. DOI: 10.1016/j.foodchem.2008.07.090.

[98] Nicoli, M. C.; Anese, M.; Parpinel, M. Influence of Processing on the Antioxidant Properties of Fruit and Vegetables. Trends Food Sci. Technol. 1999, 10(3), 94-100. DOI: 10.1016/S09242244(99)00023-0.

[99] Ilyas, M.; Arshad, M. U.; Saeed, F.; Iqbal, M. Antioxidant Potential and Nutritional Comparison of Moringa Leaf and Seed Powders and Their Tea Infusions. J. Anim. Plant Sci. 2015, 25(1), 226-233.

[100] Oboh, G.; Akindahunsi, A. A. Change in the Ascorbic Acid, Total Phenol and Antioxidant Activity of Sun-Dried Commonly Consumed Green Leafy Vegetables in Nigeria. Nutr. Health. 2004, 18(1), 29-36. DOI: 10.1177/026010600401800103.

[101] Shyamala, B. N.; Gupta, S.; Lakshmi, A. J.; Prakash, J. Leafy Vegetable Extracts - Antioxidant Activity and Effect on Storage Stability of Heated Oils. Innov. Food Sci. Emerg. Technol. 2005, 6(2), 239-245. DOI: 10.1016/j.ifset.2004.12.002.

[102] Viña, S. Z.; Chaves, A. R. Effect of Heat Treatment and Refrigerated Storage on Antioxidant Properties of Pre-Cut Celery (Apium graveolens L.). Int. J. Food Sci. Technol. 2008, 43(1), 44-51. DOI: 10.1111/j.1365-2621.2006.01380.x.

[103] Wangcharoen, W.; Gomolmanee, S. Antioxidant Activity Changes during Hot-Air Drying of Moringa oleifera Leaves. Maejo Int. J. Sci. Technol. 2013, 7(3), 353-363. DOI: 10.14456/ mijst.2013.29.

[104] Sukrasno,; Fidriany, I.; Anggadiredja, K.; Handayani, W. A.; Anam, K. Influence of Drying Method on Flavonoid Content of Cosmos caudatus Leaves. Res. J. Med. Plant. 2011, 5(2), 189-195. DOI: 10.3923/rjmp.2011.189.195.

[105] Olabode, Z.; Akanbi, C. T.; Olunlade, B.; Adeola, A. A. Effects of Drying Temperature on the Nutrients of Moringa (Moringa oleifera). Direct Res. J. Agric. Food Sci. 2015, 3(5), $117-122$. 
[106] Divya, P.; Puthusseri, B.; Neelwarne, B. Carotenoid Content, Its Stability during Drying and the Antioxidant Activity of Commercial Coriander (Coriandrum sativum L.) Varieties. Food Res. Int. 2012, 45(1), 342-350. DOI: 10.1016/j.foodres.2011.09.021.

[107] Cesare, D.; Forni, E.; Viscardi, D.; Nani, R. C. Changes in the Chemical Composition of Basil Caused by Different Drying Procedures. J. Agric. Food Chem. 2003, 51, 3575-3581. DOI: 10.1021/jf021080o.

[108] Ahmed, J.; Shivhare, U. S.; Singh, G.; Gupta, P. Drying Characteristics and Product Quality of Coriander Leaves. Food Bioprod. Process. 2001, 79(2), 103-106. DOI: 10.1205/ 096030801750286258.

[109] Yang, J.; Jin, X.; Chen, X. D. Investigation of the Effects of Mechanical Treatments on Cellular Structure Integrity and Vitamin C Extractability of Broccoli (Brassica oleracea L. Var. Italica) by LF-NMR. Food Funct. 2018, 9(5), 2942-2950. DOI: 10.1039/c8fo00140e.

[110] Perdana, J.; Zubia, A. A.; Kutahya, O.; Schutyser, M.; Fox, M. Spray Drying of Lactobacillus plantarum WCFS1 Guided by Predictive Modeling. Dry. Technol. 2015, 33(15-16), 1789-1797. DOI: 10.1080/07373937.2015.1026975.

[111] Dev, S. R. S.; Geetha, P.; Orsat, V.; Gariépy, Y.; Raghavan, G. S. V. Effects of Microwave-Assisted Hot Air Drying and Conventional Hot Air Drying on the Drying Kinetics, Color, Rehydration, and Volatiles of Moringa oleifera. Dry. Technol. 2011, 29 (12), 1452-1458. DOI: 10.1080/07373937.2011.587926.

[112] Fellows, P.;. Food Processing Technology Principles and Practice; Woodhead Publishing Limited: Cambridge, 2000.

[113] Padmini, T.; Karpagavalli, B.; Vijayalakshmi, R.; Jesupriya, P. S. Changes in Antioxidants during Heat Processing of Green Leafy Vegetables. Int. J. Agric. Food Sci. 2015, 5(4), $115-120$.

[114] Jiménez-Monreal, A. M.; García-Diz, L.; Martínez-Tomé, M.; Mariscal, M.; Murcia, M. A. Influence of Cooking Methods on Antioxidant Activity of Vegetables. J. Food Sci. 2009, 74 (3), 97-103. DOI: 10.1111/j.1750-3841.2009.01091.x.

[115] Thummakomma, K.; Prashanthi, M.; Rajeswari, K. Effect of Cooking Methods on Bioactive Compounds in Vegetables. Int. J. Chem. Stud. 2018, 6(4), 3310-3315. DOI: 10.13140/ RG.2.2.35490.27844.

[116] Pérez-burillo, S.; Rufián-henares, J. Á.; Pastoriza, S. Effect of Home Cooking on the Antioxidant Capacity of Vegetables: Relationship with Maillard Reaction Indicators. Food Res. Int. 2018. DOI: $10.1016 /$ j.foodres.2018.12.007. 